\title{
Article \\ New Integrated Process for the Efficient Production of Methanol, Electrical Power, and Heating
}

\author{
Alireza Khatami Jouybari ${ }^{1, *}$, Adrian Ilinca ${ }^{1}$ (D) and Bahram Ghorbani ${ }^{2}$ (D) \\ 1 Department of Mathematics, Computer Science and Engineering, University of Quebec at Rimouski (UQAR), \\ 300 All. des Ursulines, Rimouski, QC G5L 3A1, Canada; adrian_ilinca@uqar.ca \\ 2 Faculty of Engineering Modern Technologies, Amol University of Special Modern Technologies, \\ Amol 4615664616, Iran; b.ghorbani@ausmt.ac.ir \\ * Correspondence: alireza.khatamijouybari@uqar.ca
}

check for updates

Citation: Khatami Jouybari, A.; Ilinca, A.; Ghorbani, B. New Integrated Process for the Efficient Production of Methanol, Electrical Power, and Heating. Energies 2022, 15, 1054 https://doi.org/10.3390/en15031054

Academic Editor: Devinder Mahajan

Received: 20 December 2021

Accepted: 25 January 2022

Published: 31 January 2022

Publisher's Note: MDPI stays neutral with regard to jurisdictional claims in published maps and institutional affiliations.

Copyright: (C) 2022 by the authors. Licensee MDPI, Basel, Switzerland. This article is an open access article distributed under the terms and conditions of the Creative Commons Attribution (CC BY) license (https:// creativecommons.org/licenses/by/ $4.0 /)$.

\begin{abstract}
In this paper, a novel process is developed to cogenerate $4741 \mathrm{~kg} / \mathrm{h}$ of methanol, $297.7 \mathrm{~kW}$ of electricity, and 35.73 ton/h of hot water, including a hydrogen purification system, an absorptioncompression refrigeration cycle (ACRC), a regenerative Organic Rankine Cycle (ORC), and parabolic solar troughs. The heat produced in the methanol reactor is recovered in the ORC and ACRC. Parabolic solar troughs provide thermal power to the methanol distillation tower. Thermal efficiencies of the integrated structure and the liquid methanol production cycle are $78.14 \%$ and $60.91 \%$, respectively. The process's total exergy efficiency and irreversibility are $89.45 \%$ and $16.89 \mathrm{MW}$. The solar thermal collectors take the largest share of exergy destruction $(34 \%)$, followed by heat exchangers $(30 \%)$ and mixers (19\%). Based on the sensitivity analysis, D17 (mixture of $\mathrm{H}_{2}$ and low-pressure fuel gas before separation) was the most influential stream affecting the performance of the process. With the temperature decline of stream D17 from -139 to $-149{ }^{\circ} \mathrm{C}$, the methanol production rate and the total thermal efficiency rose to $4741.2 \mathrm{~kg} / \mathrm{h}$ and $61.02 \%$, respectively. Moreover, the growth in the hydrogen content from $55 \%$ to $80 \%$ molar of the feed gas, the flow rate of liquid methanol, and the total exergy efficiency declined to $4487 \mathrm{~kg} / \mathrm{h}$ and $86.05 \%$.
\end{abstract}

Keywords: integrated structure; hydrogen purification; methanol production; absorption-compression refrigeration unit; parabolic solar trough; regenerative Organic Rankine cycle

\section{Introduction}

The increasing rate of fossil fuel consumption has led to a global environmental crisis and depletion of conventional energy resources. These issues required the exploitation of renewable energy sources to produce alternative fuels [1]. Hydrogen, as a green fuel and the most abundant element of the periodic table in the world, has absorbed researchers' attention in this regard. It can produce a comparatively high heat of combustion, leaving just water vapor [2]. As hydrogen has a remarkably low atomic mass, its storage and transportation are not cost-effective. A proper solution for this problem is hydrogen liquefaction, which optimizes its energy density [3]. However, the liquefaction process has high investment costs and heat loss, low efficiency, and the need for state-of-the-art technologies [4]. Instead of hydrogen liquefaction for energy transportation, by adding $\mathrm{CO}_{2}$ into hydrogen, it can be converted into liquid methanol, which has a higher liquefaction temperature and safety and the merit of decreasing the $\mathrm{CO}_{2}$ concentration in the atmosphere.

The source of hydrogen for methanol production should have an acceptable range of purification. Extensive studies have been separately carried out on hydrogen purification and methanol production. The method for extracting impurities from hydrogen can be divided into three main categories: membrane separation, pressure swing absorption, and cryogenic absorption methods. Absorption and cryogenic techniques are employed for purification at high-capacity rates. The cryogenic process has the maximum recovery rate 
but provides hydrogen at minimum purity. As the energy consumption and purification cost in the cryogenic method are high, most studies have focused on optimizing its energy consumption [5].

The exergy and exergoeconomic analyses of a structure for hydrogen purification were carried out by Mehrpooya et al. [6]. They utilized a water-ammonia diffusion-absorption refrigeration cycle to precool hydrogen at $-32.61{ }^{\circ} \mathrm{C}$ and liquefied nitrogen for its cooling in the final stage. The total exergy efficiency of the structure, the outlet hydrogen purity, and the coefficient of performance of the refrigeration cycle were reported to be $93.82 \%$, $88 \%$ molar, and 0.424, respectively. Aasadnia et al. [7] applied the propane cryogenic cycle at $-40{ }^{\circ} \mathrm{C}$ and the liquid nitrogen cycle at $-155^{\circ} \mathrm{C}$ to supply required cooling for the hydrogen purification process designed to provide $88 \%$ molar $\mathrm{H}_{2}$, having the total exergy efficiency and hydrogen recovery rate of $91.73 \%$ and $25.1 \%$, respectively. Hamedi et al. [8] studied the optimization of energy consumption in extracting nitrogen from natural gas using the Particle Swarm Optimization (PSO) algorithm. In this study, the nitrogen content of feed gas in single- or multi-column units is considered between $5 \%$ and $70 \%$.

A stream with the main components of hydrogen and methane is the side product of many industrial processes. In this regard, $\mathrm{Xu}$ et al. [9] proposed four different processes for the cogeneration of Liquid Hydrogen $\left(\mathrm{LH}_{2}\right)$ and Liquid Natural Gas (LNG) from the mentioned compound. Results showed that the purities of LNG in these systems were over 99.99\%, and the Specific Energy Consumptions (SEC) were between 18.01 and $41.72 \mathrm{kWh} / \mathrm{kmol}$. In another study, Xu et al. [10] developed three integrated structures for the simultaneous generation of $\mathrm{LH}_{2}$ and LNG using the helium reverse Brayton cycle from the feed containing hydrogen and methane gases. These systems' energy consumption and exergy efficiencies were $21.94-54.78 \mathrm{kWh} / \mathrm{kmol}$ (feedstock gas) and 13-66.5\%. The multi-stage helium expansion refrigeration cycle is used in an integrated structure for the cogeneration of $\mathrm{LH}_{2}$ and LNG by Xu et al. [11]. The outlet stream from the coke oven gas containing methane and hydrogen fed the integrated structure. This system recovered hydrogen and methane with the rates of $99.68 \%$ and $97.92 \%$, respectively.

Carbon dioxide, the main gas that contributes to global warming, can be absorbed or recovered by some processes, producing methanol, methane, or formic acid to decrease its atmospheric concentration. Amongst all, methanol is the most favorable due to its application in internal combustion engines and fuel cells and easing hydrogen storage [12-14]. Hosseini et al. [15] proposed an integrated structure for the tri-generation of methanol, power, and heat, including subsystems of natural gas reforming units, methanol production process, MCFC fuel cells, and combined heat and power (CHP) systems, resulting in the total energy and exergy efficiencies of $58.4 \%$ and $83.7 \%$ for the integrated structure and of $80.4 \%$ and $54.1 \%$ for methanol production. In addition, as the methanol production reaction is exothermic, the heat can serve in the CHP systems to keep the temperature of the process constant.

Mosaffa et al. [16] developed an integrated structure with energy and exergy efficiencies of $48.8 \%$ and $32.7 \%$, respectively, for the cogeneration of hydrogen, methanol, and power. Ishaq et al. [17] employed wind turbines to supply the necessary power in a PEM electrolyzer for hydrogen production, subsequently combined with $\mathrm{CO}_{2}$ in a methanol reactor. Carbon dioxide in this study was provided from the power plant's flue gas. Their integrated structure's energy and exergy efficiencies were calculated to be $40.5 \%$ and $42.3 \%$, respectively. Nami et al. [18] proposed an integrated structure for the simultaneous production of methanol, carbon dioxide, and hydrogen, including the PEM electrolyzer, the oxyfuel power plant, and the ORC. The geothermal power was used to supply the ORC to convert thermal power into electricity. This structure's energy and exergy efficiencies and sustainability index were $14.7 \%, 42.43 \%$, and 1.737 , respectively.

Monnerie et al. [19] modeled a methanol production system including concentrating solar energy and a thermochemical cycle using Aspen Plus software. The price for methanol production was estimated at 1.14 Euro/Liter. An integrated structure including the alkaline electrolyzer, the ORC, the absorption refrigeration cycle, and the methanol production 
cycle was developed by Ghorbani et al. [20] to simultaneously produce biomethane and biomethanol. Parabolic solar troughs supply the necessary thermal power of the ORC. The required $\mathrm{CO}_{2}$ in this structure was provided by biogas upgrading. This integrated structure's energy and exergy efficiencies were $92.47 \%$ and $45.92 \%$.

In another study, Ghorbani et al. [21] developed an integrated structure for cogeneration of methanol, LNG, and helium by using the separation unit to extract helium from natural, methanol synthesis process, and solar dish collectors to supply the required heat of the natural gas reforming process for hydrogen production. This structure's energy and exergy efficiencies were $88.48 \%$ and $93.79 \%$, respectively.

The compressor in the evaporation compression cycle is replaced by an absorber and a generator in absorption refrigeration cycles. The generator, pump, and absorber set in an absorption process are named thermal compressors. In fact, in the absorption system, the thermal power in generators is converted into cooling. The water-ammonia absorption cycles are suitable for providing cooling at temperatures around $-30{ }^{\circ} \mathrm{C}$ and atmospheric pressure. For lower temperature ranges, the compression-absorption cycle can be used. Mehrpooya et al. [22] utilized a compression-absorption refrigeration cycle for the precooling stage of a natural gas liquefaction cycle at $-54.62{ }^{\circ} \mathrm{C}$. The refrigeration capacity per mass flow of flue gas and the coefficient of performance of the compression-absorption cycle were 0.0606 and $0.2539 \mathrm{MJ} / \mathrm{kg}$, respectively. Chen et al. [23] developed a refrigeration cycle including subsystems of a single-stage absorption cycle and an absorption-refrigeration cycle. The hot and cold temperatures sources were 200 and $-15^{\circ} \mathrm{C}$. Exergy, economic, and environmental analyses of an ACRC at $-54.62{ }^{\circ} \mathrm{C}$ were done by Mousavi et al. [24]. The ORC supplied the electrical power. The flue gas heat provided the necessary thermal power in the compression-absorption refrigeration cycle and the ORC at $350{ }^{\circ} \mathrm{C}$. The coefficient of performance in this process was 0.268 .

Several studies have been carried out to develop the extraction from fuels and purification of hydrogen or methanol production. The main goals of the studies have been the optimization of the required heat, power generation and consumption, economic costs, and environmental friendliness. In some studies, the combined pinch and exergy analyses were applied to assess the cryogenic hydrogen purification systems. However, based on the literature review, not a lot of studies have been performed to develop an integrated structure for hydrogen purification and methanol production using renewable energies. This study aims to fill the gap of recent studies, offer an efficient method, and facilitate energy transfer by converting hydrogen into liquid methanol. The proposed integrated structure contains the hydrogen purification cycle, the liquid methanol production structure, the regenerative ORC, the ACRC, and parabolic solar troughs designed to simultaneously produce liquid methanol, electrical power, and heat. Parabolic solar troughs are designed based on the environmental condition of Bushehr city, Iran. Thermodynamic, exergy, and sensitivity analyses are completed to assess the integrated structure.

\section{Description and Modeling}

Hydrogen is considered an ideal fuel thanks to its merits of eco-friendliness and having a higher heating value compared to fossil fuels. However, the produced hydrogen in most processes is not pure, limiting its miscellaneous utilization. For example, except helium, nearly every impurity of $\mathrm{H}_{2}$ converts into a solid state, choking heat exchangers and valves in the hydrogen liquefaction process. Several methods have been developed for hydrogen purification, with the cryogenic method known as the best option on a large recovery scale. Besides, hydrogen storage and transportation are challenging, whether as a compressed gas or liquefied. Purified hydrogen can be converted into liquid methanol and transported as a safe energy carrier to avoid the high costs of hydrogen liquefaction. This paper proposes a brand-new integrated structure for the simultaneous production of liquid methanol, electrical power, and heat, including subsystems of parabolic solar troughs and cryogenic purification, liquid methanol production, absorption-compression refrigeration, and regenerative ORC. Figure 1 illustrates the block flow diagram (BFD) of the 
integrated structure with the production capacity of $4741 \mathrm{~kg} / \mathrm{h}$ of liquid methanol, $297.7 \mathrm{~kW}$ of electricity, and 35.73 ton/h of hot water. Hydrogen from the cryogenic purification cycle and carbon dioxide enter the methanol production cycle. Solar thermal collectors supply the heating required in the methanol distillation column. Regenerative ORC and the absorptioncompression refrigeration cycle absorb the excess heat from the methanol production cycle to produce power and provide cooling for the purification cycle. Figure 2 depicts the integrated structure's process flow diagram (PFD). The Peng-Robinson equation of state and Aspen HYSYS V10.0 software are used for the simulation of the system consisting of these subsystems:

1. The cryogenic hydrogen purification cycle was developed in Aspen HYSYS V10.0 software. Pinch analysis in the forms of cold and hot composite curves was applied to integrate the process core and refrigeration cycle.

2. The liquid methanol production cycle was modeled in Aspen HYSYS V10.0 software and fed by hydrogen with $88.05 \%$ purity and $\mathrm{CO}_{2}$.

3. A regenerative ORC was developed in Aspen HYSYS V10.0 software and fed by the excess heat of the liquid methanol production cycle.

4. The absorption-compression refrigeration cycle was modeled in Aspen HYSYS V10.0 software and employed to precool the hydrogen purification cycle.

5. Parabolic solar collectors were modeled using MATLAB V10.0 m-file. They are used to supply thermal power in the methanol distillation tower.

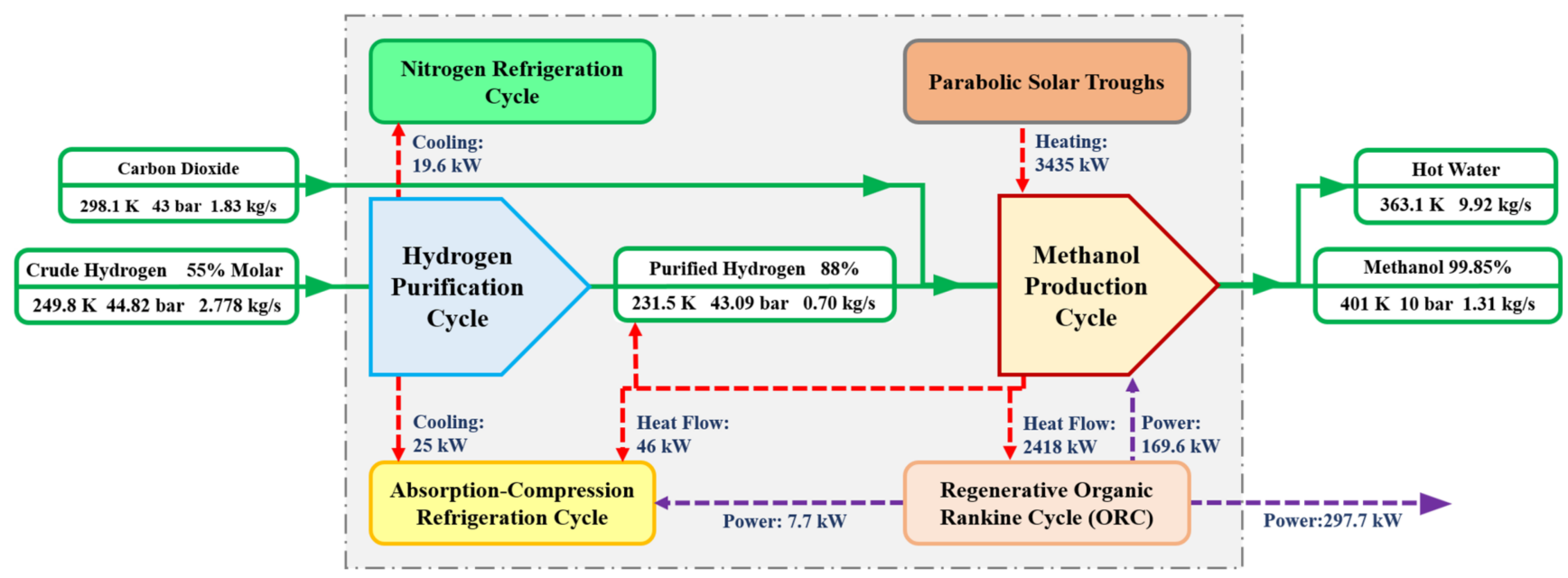

Figure 1. The block flow diagram (BFD) of the integrated structure.

The following assumptions were made for the model:

1. Pressure drop in heat exchangers and flash drums and heat loss are ignored.

2. Utility water at $25^{\circ} \mathrm{C}$ provides cooling in heat exchangers.

3. Convection heat losses in evacuated tubes of parabolic solar troughs are ignored.

4. The parabolic shape of solar collectors is considered symmetric.

5. The generator in the absorption-compression refrigeration cycle is considered as the combination of a distillation column and a boiler. Besides, the absorption of ammonia in water is modeled by a heat exchanger.

The algorithm for the design and development of the novel integrated structure is illustrated in Figure 3. 


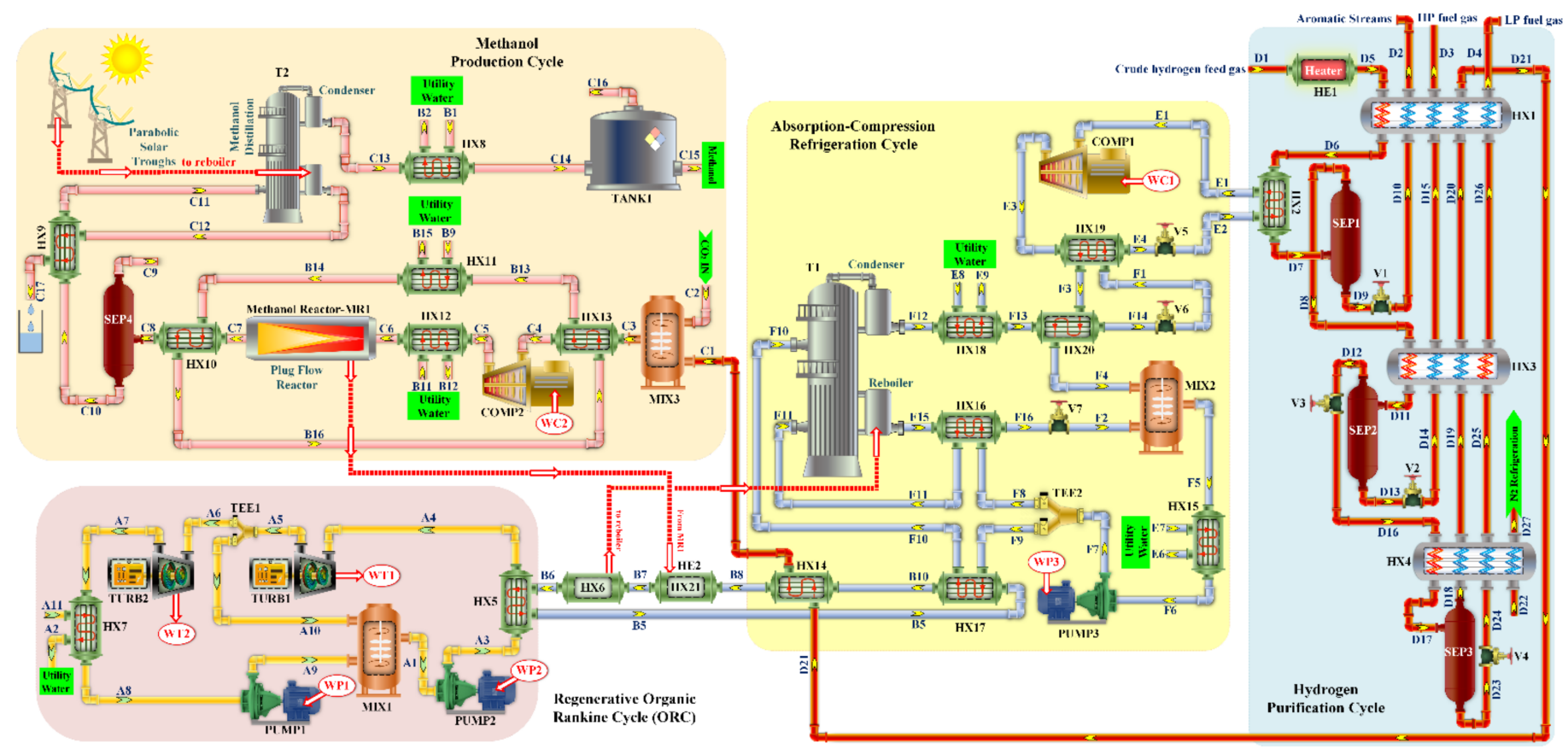

Figure 2. The process flow diagram (PFD) of the integrated structure.

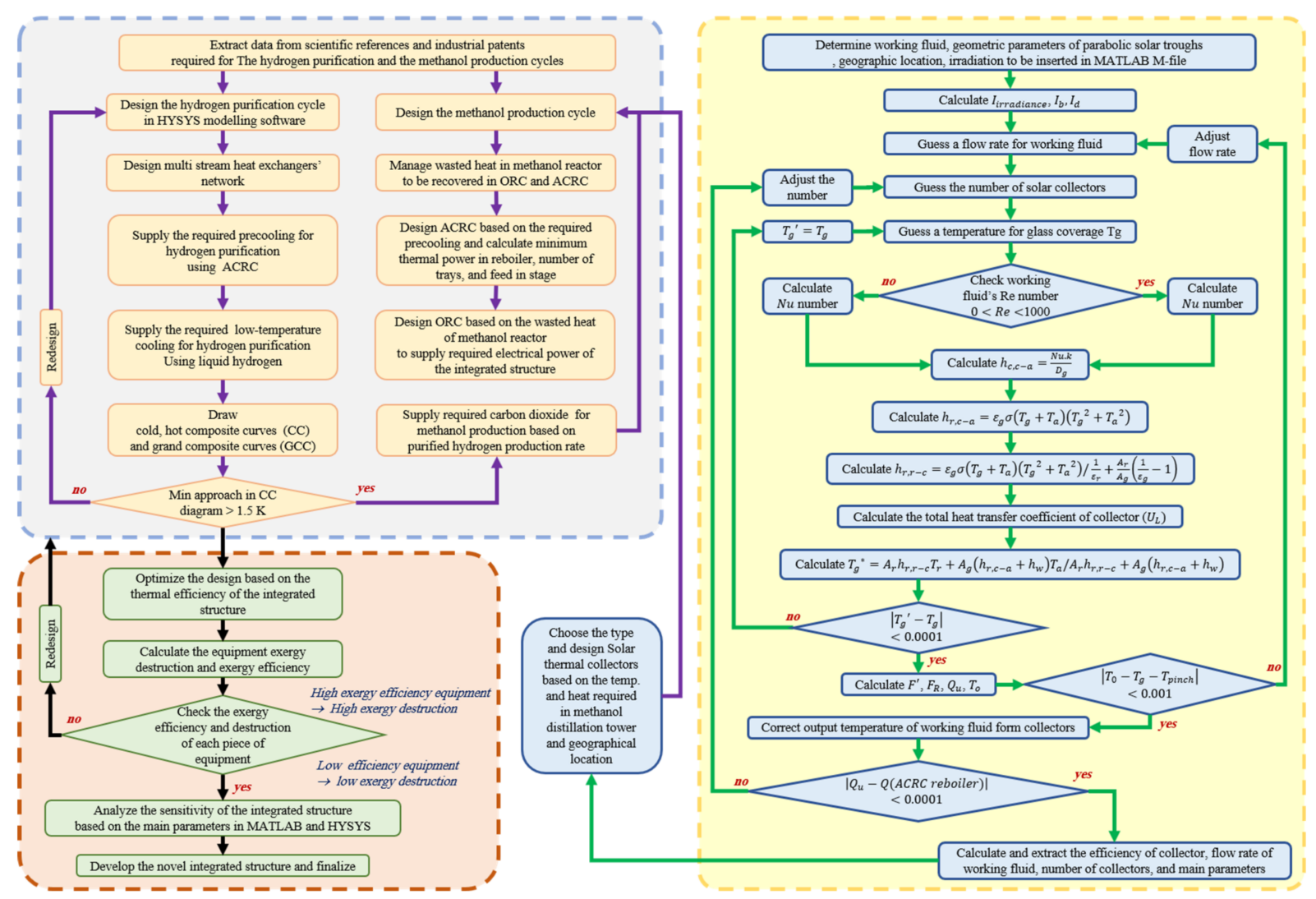

Figure 3. The algorithm of the design and development of the novel integrated structure.

\subsection{Cryogenic Hydrogen Purification Cycle}

Methods for hydrogen purification can be categorized into three main groups: membrane separation, pressure swing absorption, and cryogenic absorption. Here, the cryogenic absorption method was chosen. This technology is based on the fact that each component in the feed gas has a different boiling point from other components, helping it to 
be liquefied and extracted from the mixture in a separator. Information on the stream and equipment of the cryogenic hydrogen purification cycle is provided in [6,7]. Table 1 provides information regarding the component molar fractions of streams in the integrated structure. The feed gas stream of crude hydrogen (stream D1) contains $55 \%$ hydrogen, $39 \%$ methane, $2 \%$ ethane, $1 \%$ propane, $2 \%$ nitrogen, and $1 \%$ benzene (molar). Stream D1, after preheating in the HE1 exchanger, enters the HX1 exchanger in 44.82 bar and $-23.33{ }^{\circ} \mathrm{C}$ to be cooled to $-34.44{ }^{\circ} \mathrm{C}$. To provide required precooling in the purification cycle, the ACRC was employed. Two-phase stream D7 enters the flash drum (Sep1) to separate most of its liquid benzene and propane contents. After a pressure drop in the V1 throttling valve, these liquids first enter the HX1 exchanger (stream D10) in $-33.5^{\circ} \mathrm{C}$ and 17.24 bar to provide cooling for the internal stream D5 and finally leave the cycle as D2 (aromatic stream). Gaseous stream D8 from the Sep1 flash drum enters the HX3 exchanger and its temperature drops to $-134.4{ }^{\circ} \mathrm{C}$. The output stream D11 enters the next Sep2 flash drum. In this stage, the liquid stream D13 containing 86\% molar methane, after passing through the V2 throttling valve, enters the HX3 and HX1 exchangers, respectively, to help with the precooling of feed gas and leaves the cycle as stream D3 (high-pressure fuel gas). The outlet stream D12 from the above Sep2 flash drum enters the V3 throttling valve and, after a pressure drop to 43.09 bar, passes through the HX4 exchanger, and its temperature drops to $-148.9{ }^{\circ} \mathrm{C}$. The liquid and gaseous parts of stream D17 separate in the Sep3 flash drum into liquid stream D23 of 95.08\% molar methane and stream D18 of $88.5 \%$ molar hydrogen. Stream D4 firstly loses its pressure from 74 to 3.447 bar in the V4 throttling valve. Then, it provides cooling for the inlet stream in the HX4, HX3, and HX1 exchangers, and finally, leaves the cycle as stream D4 (low-pressure fuel gas). The reason for using the $\mathrm{V} 1$ to $\mathrm{V} 4$ valves is to decrease the temperature of streams by pressure drop to maximize their potential in supplying cooling for the inlet stream. The remaining required low-temperature cooling is designed to be provided by liquid nitrogen (stream D22). Stream D18 supplies cooling in the HX4, HX3, and HX1 exchangers and then goes to the methanol production cycle at 43.09 bar and $-41.64{ }^{\circ} \mathrm{C}$.

Table 1. Compositions of some important streams (molar\%).

\begin{tabular}{ccccccccccccc}
\hline Stream & $\mathbf{H}_{\mathbf{2}}$ & $\mathbf{C H}_{\mathbf{4}}$ & $\mathbf{C}_{\mathbf{2}} \mathbf{H}_{\mathbf{6}}$ & $\mathbf{C}_{\mathbf{3}} \mathbf{H}_{\mathbf{8}}$ & $\mathbf{N}_{\mathbf{2}}$ & $\mathbf{C}_{\mathbf{6}} \mathbf{H}_{\mathbf{6}}$ & $\mathbf{C O}_{\mathbf{2}}$ & $\mathbf{H}_{\mathbf{2}} \mathbf{O}$ & $\mathbf{N H}_{\mathbf{3}}$ & $\mathbf{R}-\mathbf{1 1 3}$ & $\mathbf{C} \mathbf{H}_{\mathbf{3}} \mathbf{O H}$ \\
\hline A1 & 0 & 0 & 0 & 0 & 0 & 0 & 0 & 0 & 0 & 1 & 0 \\
C3 & 0.71 & 0.08 & 0.00 & 0.00 & 0.02 & 0.00 & 0.19 & 0.00 & 0.00 & 0.00 & 0.00 \\
C7 & 0.22 & 0.12 & 0.00 & 0.00 & 0.03 & 0.00 & 0.00 & 0.31 & 0.00 & 0.00 & 0.31 \\
C9 & 0.57 & 0.33 & 0.00 & 0.00 & 0.09 & 0.00 & 0.00 & 0.00 & 0.00 & 0.00 & 0.01 \\
C11 & 0.00 & 0.00 & 0.00 & 0.00 & 0.00 & 0.00 & 0.00 & 0.50 & 0.00 & 0.00 & 0.50 \\
C12 & 0.00 & 0.00 & 0.00 & 0.00 & 0.00 & 0.00 & 0.00 & 1.00 & 0.00 & 0.00 & 0.00 \\
C13 & 0.00 & 0.00 & 0.00 & 0.00 & 0.00 & 0.00 & 0.00 & 0.00 & 0.00 & 0.00 & 1.00 \\
D1 & 0.55 & 0.39 & 0.02 & 0.01 & 0.02 & 0.01 & 0 & 0 & 0 & 0 & 0 \\
D8 & 0.56 & 0.39 & 0.02 & 0.01 & 0.02 & 0.00 & 0 & 0 & 0 & 0 & 0 \\
D9 & 0.01 & 0.07 & 0.04 & 0.10 & 0.00 & 0.78 & 0 & 0 & 0 & 0 & 0 \\
D12 & 0.79 & 0.18 & 0.00 & 0.00 & 0.02 & 0.00 & 0 & 0 & 0 & 0 & 0 \\
D13 & 0.03 & 0.87 & 0.06 & 0.03 & 0.01 & 0.00 & 0 & 0 & 0 & 0 & 0 \\
D18 & 0.88 & 0.09 & 0.00 & 0.00 & 0.02 & 0.00 & 0 & 0 & 0 & 0 & 0 \\
D22 & 0.00 & 0.00 & 0.00 & 0.00 & 1.00 & 0.00 & 0 & 0 & 0 & 0 & 0 \\
D23 & 0.03 & 0.95 & 0.00 & 0.00 & 0.02 & 0.00 & 0 & 0 & 0 & 0 & 0 \\
E1 & 0 & 0 & 0 & 0 & 0 & 0 & 1 & 0 & 0 & 0 & 0 \\
F5 & 0 & 0 & 0 & 0 & 0 & 0 & 0 & 0.66 & 0.34 & 0 & 0 \\
F8 & 0 & 0 & 0 & 0 & 0 & 0 & 0 & 0.65 & 0.35 & 0 & 0 \\
F9 & 0 & 0 & 0 & 0 & 0 & 0 & 0 & 0.65 & 0.35 & 0 & 0 \\
F12 & 0 & 0 & 0 & 0 & 0 & 0 & 0 & 0.00 & 1.00 & 0 \\
F15 & 0 & 0 & 0 & 0 & 0 & 0 & 0 & 0.80 & 0.20 & 0 & 0 \\
\hline
\end{tabular}

\subsection{Absorption-Compression Refrigeration Cycle}

Ammonia-water absorption refrigeration cycles are widely employed in industrial and commercial sectors where the temperature of the evaporator is close to the water freezing point. As the freezing point of ammonia is $-77^{\circ} \mathrm{C}$, the absorption refrigeration cycles of water-ammonia are used in low-temperature processes in industries with the ability to 
provide cooling at $-30{ }^{\circ} \mathrm{C}$. Absorption and compression cycles need to be combined to provide cooling in lower temperatures. In the present paper, the absorption-compression refrigeration cycle provides precooling for the cryogenic hydrogen purification cycle. Initial information on the stream and equipment of the absorption-compression refrigeration cycle is provided in [25]. ACRC includes the generator or desorber for water-ammonia separation in the distillation tower and reboiler, the purifier for the extraction of remaining water droplets from ammonia in the condenser of the distillation tower, the condenser for the liquefaction of purified ammonia (the HX18 exchanger), the evaporator to supply required cooling of the cycle by $\mathrm{CO}_{2}$ evaporation (the $\mathrm{HX} 2$ exchanger), the absorbent for the absorption of water in ammonia (the HX15 exchanger), and the $\mathrm{CO}_{2}$ compression refrigeration cycle to provide cooling at $-42.07^{\circ} \mathrm{C}$.

In ACRC, stream F6, containing ammonia and water at $35^{\circ} \mathrm{C}$, enters Pump3 to increase its pressure from 270 to $1356 \mathrm{kPa}$, the required pressure of the generator. Stream F7 with $64.73 \%$ molar water and $35.27 \%$ molar ammonia is divided into streams F8 and F9 before entering the generator. Stream F8 enters the HX18 exchanger and, after a temperature increase to $114.2^{\circ} \mathrm{C}$, enters the distillation tower as stream F11. Stream F9 enters the HX17 exchanger and, after warming to $113.8^{\circ} \mathrm{C}$, enters the fourth tray of the distillation tower as stream F10. The required thermal power in this step is supplied by the wasted heat of the methanol reactor.

Part of the ammonia of the mixture entering the distillation tower (T1) evaporates by receiving the heat from the methanol reactor. This ammonia stream contains a low fraction of water distractable by the condenser situated at the top of the T1 tower. The generator and purifier are modeled in Aspen HYSYS V10.0 software as a distillation tower. The low ammonia content mixture leaves the reboiler of the tower with $79.33 \%$ molar water and $20.67 \%$ molar ammonia. The utility water at $25^{\circ} \mathrm{C}$ supplies the required cooling in the purifier (condenser). The purified gaseous ammonia at $59.19^{\circ} \mathrm{C}$ (stream F12) enters the HX18 exchanger to be liquefied and, after heat recovery in the HX20 exchanger, enters the V8 throttling valve to provide required cooling for the $\mathrm{CO}_{2}$ compression refrigeration cycle. After being combined with the outlet stream of the reboiler, the returning stream loses its temperature in the HX15 exchanger and enters Pump3.

The $\mathrm{CO}_{2}$ compression refrigeration cycle after a pressure increase in the Comp1 compressor enters the HX19 exchanger and its temperature drops to $-15.41^{\circ} \mathrm{C}$. Then, the outlet stream from the HX19 exchanger enters the V 5 throttling valve to decrease its pressure to $900 \mathrm{kPa}$. The pressure drop leads to the temperature decrease of the $\mathrm{CO}_{2}$ to $-42.07^{\circ} \mathrm{C}$, helping the $\mathrm{HX} 2$ exchanger provide the required precooling in the hydrogen purification cycle. Subsequently, the $\mathrm{CO}_{2}$ stream enters the compressor to increase its pressure at $4000 \mathrm{kPa}$.

\subsection{Liquid Methanol Production Cycle}

Due to the low boiling point of hydrogen and safety hazards associated with its storage and transport, hydrogen conversion into methanol for long-distance energy transportation is recommended. In the methanol production cycle, the purified hydrogen stream from the hydrogen purification cycle is mixed with stream $\mathrm{C} 2\left(\mathrm{CO}_{2}\right)$ to enter the Comp2 compressor and the HX12 exchanger, and its pressure and temperature rise to $50 \mathrm{bar}$ and $200^{\circ} \mathrm{C}$. Finally, the outlet stream (C6) enters the methanol production reactor, modeled as a plug flow reactor in Aspen HYSYS V10.0 software. In this kinetic model, two independent reactions (hydrogenation of carbon dioxide and reverse water-gas shift reaction) out of the three following dependent reactions are considered [26]:

$$
\begin{gathered}
\mathrm{CO}+2 \mathrm{H}_{2} \rightleftarrows \mathrm{CH}_{3} \mathrm{OH} \\
\mathrm{CO}_{2}+3 \mathrm{H}_{2} \rightleftarrows \mathrm{CH}_{3} \mathrm{OH}+\mathrm{H}_{2} \mathrm{O} \\
\mathrm{CO}_{2}+\mathrm{H}_{2} \rightleftarrows \mathrm{CO}+\mathrm{H}_{2} \mathrm{O}
\end{gathered}
$$


Methanol production is an exothermic reaction. Its wasted heat is recovered in ACRC to provide thermal power and in ORC for electrical power production. Stream C7 enters the HX10 exchanger and, after dropping its temperature to $44{ }^{\circ} \mathrm{C}$, enters the Sep4 flash drum (as a two-phase flow). The gaseous mixture of hydrogen and hydrocarbons (stream C10) leaves the Sep4 flash drum from above to enter the HX9 exchanger and increase its temperature to $95^{\circ} \mathrm{C}$. The liquid mixture of methanol and water from the Sep 4 flash drum enters the T2 methanol distillation tower, the water content is extracted, and gaseous methanol (stream C13) leaves the tower from above. Stream C13 enters the HX8 exchanger to be liquefied and stored at $127.8^{\circ} \mathrm{C}$ and 10 bar. Parabolic solar troughs are employed to provide thermal heating required in the boiler of the methanol distillation tower.

\subsection{Regenerative Organic Rankine Cycle}

The excess heat from the methanol reactor could be recovered in the regenerative ORC, enhancing the efficiency of the integrated structure. Considering the inlet temperature of the HX5 exchanger $\left(199^{\circ} \mathrm{C}\right)$, the power generation cycle is chosen to be a regenerative ORC. First, stream A1 at $138^{\circ} \mathrm{C}$ enters Pump2 and, after a pressure increase from 10 to 25 bar, passes through the HX5 exchanger to be heated at $192.5^{\circ} \mathrm{C}$, ready to enter the Turb1 turbine. The outlet stream from the Turb1 turbine (stream A5) with a pressure of 10 bar divides into two streams, A5 and A6. Stream A6, with a 0.8 bar pressure drop in the Turb2 turbine, provides $319.4 \mathrm{~kW}$ of power, and subsequently enters the HX7 condenser to cool at $28{ }^{\circ} \mathrm{C}$ using utility water at $25^{\circ} \mathrm{C}$. Next, the condenser's outlet stream enters Pump1 to retrieve its primary pressure of 10 bar. Then, after being mixed, streams A9 and A10 create stream A1 in the first step of the cycle.

\subsection{Parabolic Solar Troughs}

Parabolic solar troughs are employed as solar thermal collectors to provide $3435 \mathrm{~kW}$ of thermal power for the methanol production cycle. This type of collector can deliver heat at the temperature range required in the methanol distillation tower. The climatic condition of Bushehr city (with geographic coordinates of $28.92^{\circ} \mathrm{N}, 50.82^{\circ} \mathrm{E}$, and $10 \mathrm{~m}$ height above the sea level) serves for the design of solar collectors. The following equations are used to determine the amount of absorbed radiation in parabolic solar troughs [27]:

$$
\begin{gathered}
\mathrm{I}_{\text {irradiance }}=\mathrm{I}_{\mathrm{b}}+\mathrm{I}_{\mathrm{d}}=\mathrm{I}_{\mathrm{bn}} \cos \theta+\mathrm{I}_{\mathrm{d}} \\
\mathrm{I}_{\mathrm{bn}}=\mathrm{A} \exp \left[-\frac{\mathrm{B}}{\cos \theta}\right] \\
\mathrm{I}_{\mathrm{d}}=\mathrm{C} \times \mathrm{I}_{\mathrm{bn}}
\end{gathered}
$$

where $I_{b}, I_{d}$, and $\theta$ are direct beam radiation, sky diffuse radiation, and angle of incidence, respectively. The area of the receiver $\left(A_{r}\right)$, glass coverage area $\left(A_{g}\right)$, and the area of collector opening $\left(\mathrm{A}_{\mathrm{a}}\right)$ are calculated as follows:

$$
\begin{gathered}
\mathrm{A}_{\mathrm{r}}=\pi \mathrm{D}_{\mathrm{o}} \mathrm{L} \\
\mathrm{A}_{\mathrm{g}}=\pi \mathrm{D}_{\mathrm{g}} \mathrm{L} \\
\mathrm{A}_{\mathrm{a}}=\left(\mathrm{W}-\mathrm{D}_{\mathrm{g}}\right) \mathrm{L}
\end{gathered}
$$

$\mathrm{D}_{0}, \mathrm{D}_{\mathrm{g}}, \mathrm{W}$, and $\mathrm{L}$ are the outer diameter of the tubular receiver, the diameter of glass coverage, the width of the opening, and the length of the parabolic solar trough, respectively. For the modeling of the collector, in the beginning, a temperature for the glass coverage is guessed $\left(\mathrm{T}_{\mathrm{g}}\right)$ to determine the heat transfers performed by thermal convection and radiation. The real temperature of the glass coverage is calculated using the trial-and-error 
method, ignoring the heat transfer with the reflector. The heat transfer coefficient of the thermal convection due to the wind stream $\left(\mathrm{h}_{\mathrm{c}, \mathrm{c}-\mathrm{a}}=\mathrm{h}_{\mathrm{w}}\right)$ is calculated as follows [28]:

$$
\begin{gathered}
\mathrm{Nu}=0.4+0.54(\operatorname{Re})^{0.52} \quad 0.1<\operatorname{Re}<1000 \\
\mathrm{Nu}=0.3(\operatorname{Re})^{0.6} \quad 1000<\operatorname{Re}<50,000 \\
\mathrm{~h}_{\mathrm{c}, \mathrm{c}-\mathrm{a}}=\mathrm{h}_{\mathrm{w}}=\frac{\mathrm{Nu} \cdot \mathrm{k}}{\mathrm{D}_{\mathrm{g}}}
\end{gathered}
$$

The heat transfer coefficient of the thermal radiation from the glass coverage to its surrounding area $\left(\mathrm{h}_{\mathrm{r}, \mathrm{c}-\mathrm{a}}\right)$ is determined using Equation (13):

$$
\mathrm{h}_{\mathrm{r}, \mathrm{c}-\mathrm{a}}=\varepsilon_{\mathrm{g}} \sigma\left(\mathrm{T}_{\mathrm{g}}+\mathrm{T}_{\mathrm{a}}\right)\left(\mathrm{T}_{\mathrm{g}}{ }^{2}+\mathrm{T}_{\mathrm{a}}^{2}\right)
$$

The heat transfer coefficient of the thermal radiation between the receiver tube and glass coverage $\left(\mathrm{h}_{\mathrm{r}, \mathrm{r}-\mathrm{c}}\right)$ is given by Equation (14) [28]:

$$
\mathrm{h}_{\mathrm{r}, \mathrm{r}-\mathrm{c}}=\frac{\varepsilon_{\mathrm{g}} \sigma\left(\mathrm{T}_{\mathrm{g}}+\mathrm{T}_{\mathrm{a}}\right)\left(\mathrm{T}_{\mathrm{g}}{ }^{2}+\mathrm{T}_{\mathrm{a}}^{2}\right)}{\frac{1}{\varepsilon_{\mathrm{r}}}+\frac{\mathrm{A}_{\mathrm{r}}}{\mathrm{A}_{\mathrm{g}}}\left(\frac{1}{\varepsilon_{\mathrm{g}}}-1\right)}
$$

The thermal convection heat transfer between the receiver tube and glass coverage is ignored because the tube is evacuated. Considering the area of the receiver as $\mathrm{A}_{r}$, the total heat transfer coefficient of the solar collector can be calculated as follows:

$$
\mathrm{U}_{\mathrm{L}}=\left[\frac{\mathrm{A}_{\mathrm{r}}}{\left(\mathrm{h}_{\mathrm{w}}+\mathrm{h}_{\mathrm{r}, \mathrm{c}-\mathrm{a}}\right) \mathrm{A}_{\mathrm{c}}}+\frac{1}{\mathrm{~h}_{\mathrm{r}, \mathrm{r}-\mathrm{c}}}\right]^{-1}
$$

As the $U_{L}$ is calculated based on an estimated temperature for $T_{g}$, the result needs to be validated. At first, $\mathrm{T}_{\mathrm{g}}$ is calculated from Equation (16):

$$
T_{g}=\frac{A_{r} h_{r, r-c} T_{r}+A_{g}\left(h_{r, c-a}+h_{w}\right) T_{a}}{A_{r} h_{r, r-c}+A_{g}\left(h_{r, c-a}+h_{w}\right)}
$$

Then, the difference between the estimated value and the calculated value of $T_{g}$ is minimized. Having $T_{g}$, the efficiency coefficient of solar collectors is calculated by Equation (17) [28]:

$$
\mathrm{F}^{\prime}=\frac{\frac{1}{\mathrm{U}_{\mathrm{L}}}}{\frac{1}{\mathrm{U}_{\mathrm{L}}}+\frac{\mathrm{D}_{\mathrm{o}}}{\mathrm{h}_{\mathrm{fi}} \mathrm{D}_{\mathrm{i}}}+\left(\frac{\mathrm{D}_{\mathrm{o}}}{2 \mathrm{k}} \ln \frac{\mathrm{D}_{\mathrm{o}}}{\mathrm{D}_{\mathrm{i}}}\right)}
$$

The thermal collection coefficient $\left(\mathrm{F}_{\mathrm{R}}\right)$ is calculated as follows [28]:

$$
\mathrm{F}_{\mathrm{R}}=\frac{\dot{\mathrm{m}} \mathrm{c}_{\mathrm{p}}}{\mathrm{A}_{\mathrm{r}} \mathrm{U}_{\mathrm{L}}}\left[1-\exp \left(-\frac{\mathrm{U}_{\mathrm{L}} \mathrm{F}^{\prime} \mathrm{A}_{\mathrm{r}}}{\dot{\mathrm{m} c_{\mathrm{p}}}}\right)\right]
$$

The calculation of useful absorbed energy is performed based on the concept of absorbed radiation as follows [28]:

$$
\mathrm{Q}_{\mathrm{u}}=\left[\mathrm{SA}_{\mathrm{a}}-\mathrm{A}_{\mathrm{r}} \mathrm{U}_{\mathrm{r}}\left(\mathrm{T}_{\mathrm{i}}-\mathrm{T}_{\mathrm{a}}\right)\right]
$$

Finally, the output temperature of the stream $\left(T_{0}\right)$ is:

$$
\mathrm{T}_{\mathrm{o}}=\mathrm{T}_{\mathrm{i}}+\frac{\mathrm{Q}_{\mathrm{u}}}{\dot{\mathrm{m}_{\mathrm{p}}}}
$$

The average hourly changes, which are important factors contributing to the performance of solar thermal collectors, are shown in Figure 4. 


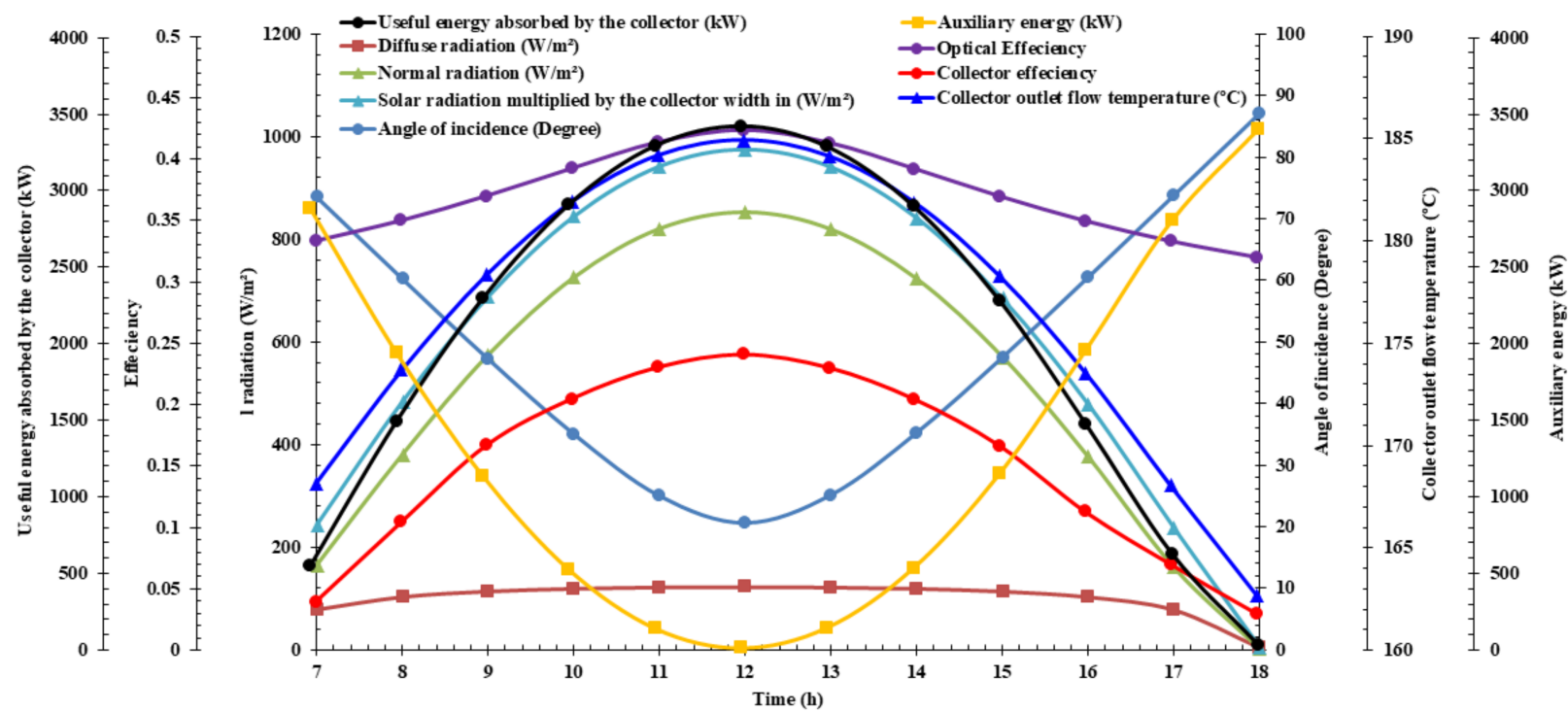

Figure 4. The average hourly changes in important values contribute to the performance of solar thermal collectors.

\section{Energy Analysis}

The energy balance equation for each piece of equipment is calculated using specific enthalpy, as follows [29]:

$$
\sum_{\text {in }} \dot{\mathrm{m}}_{\text {in }} \mathrm{h}_{\text {in }}-\sum_{\text {out }} \dot{\mathrm{m}}_{\text {out }} \mathrm{h}_{\text {out }}-\dot{\mathrm{W}}+\dot{\mathrm{Q}}=0
$$

Energy balance equations for each heat exchanger by considering the heat loss equal to zero are:

$$
\begin{gathered}
\dot{\mathrm{m}}_{\mathrm{in}, \mathrm{i}}\left(\mathrm{h}_{\mathrm{in} 1, \mathrm{i}}-\mathrm{h}_{\mathrm{in} 2, \mathrm{i}}\right)=\dot{\mathrm{m}}_{\text {out }, \mathrm{i}}\left(\mathrm{h}_{\text {out } 1, \mathrm{i}}-\mathrm{h}_{\text {out } 2, \mathrm{i}}\right) \\
\mathrm{T}_{\mathrm{in} 1, \mathrm{i}}=\mathrm{T}_{\text {out } 1, \mathrm{i}}+\Delta \mathrm{T}_{\mathrm{in}, \mathrm{HXi}}
\end{gathered}
$$

For the energy balance, Equations (23) and (24) related to pumps' and turbines' isentropic efficiency are used [29]:

$$
\begin{gathered}
\mathrm{h}_{\text {out }}=\frac{\mathrm{h}_{\text {out }}^{\mathrm{S}}-\mathrm{h}_{\text {in }}}{\eta_{\mathrm{s}}}+\mathrm{h}_{\text {in }} \\
\mathrm{h}_{\text {out }}=\left(\mathrm{h}_{\text {out }}^{\mathrm{S}}-\mathrm{h}_{\text {in }}\right) \eta_{\mathrm{s}}+\mathrm{h}_{\text {in }}
\end{gathered}
$$

The energy balance and the mass conservation equations in mixers are as follows:

$$
\begin{gathered}
\dot{\mathrm{m}}_{\mathrm{in}, 1} \mathrm{~h}_{\mathrm{in}, 1}+\dot{\mathrm{m}}_{\mathrm{in}, 2} \mathrm{~h}_{\mathrm{in}, 2}=\dot{\mathrm{m}}_{\text {out }} \mathrm{h}_{\text {out }} \\
\dot{\mathrm{m}}_{\mathrm{in}, 1}+\dot{\mathrm{m}}_{\mathrm{in}, 2}=\dot{\mathrm{m}}_{\text {out }}
\end{gathered}
$$

By combining Equations (25) and (26), the refrigerant enthalpy in the outlet stream of mixers, $\mathrm{h}_{\text {out }}$, is calculated as:

$$
\mathrm{h}_{\mathrm{out}}=\frac{\dot{\mathrm{m}}_{\mathrm{in}, 1} \mathrm{~h}_{\mathrm{in}, 1}+\dot{\mathrm{m}}_{\mathrm{in}, 2} \mathrm{~h}_{\mathrm{in}, 2}}{\dot{\mathrm{m}}_{\mathrm{in}, 1}+\dot{\mathrm{m}}_{\mathrm{in}, 2}}
$$

In separators and flash drums, the energy balance and the mass conservation equations are calculated as follows:

$$
\dot{\mathrm{m}}_{\text {in }} \mathrm{h}_{\text {in }}=\dot{\mathrm{m}}_{\text {out }, 1} \mathrm{~h}_{\text {out }, 1}+\dot{\mathrm{m}}_{\text {out }, 2} \mathrm{~h}_{\text {out }, 2}
$$




$$
\dot{\mathrm{m}}_{\text {in }}=\dot{\mathrm{m}}_{\text {out }, 1}+\dot{\mathrm{m}}_{\text {out }, 2}
$$

Based on the first law of thermodynamics, the throttling process in valves is enthalpy constant. Therefore [30]:

$$
\mathrm{h}_{\mathrm{in}}=\mathrm{h}_{\mathrm{out}}
$$

For modeling the distillation tower, Figure 5 is used, showing the overall balance in one of its stages, which is applicable for many of its design options. A vapor stream and a liquid stream enter each tray and leave it. In each tray, a vapor, liquid, or a two-phase stream goes out at the side outlet, feed enters, and products leave the tray. This helps to model towers with multiple feeds and products and with auxiliary heat exchangers.

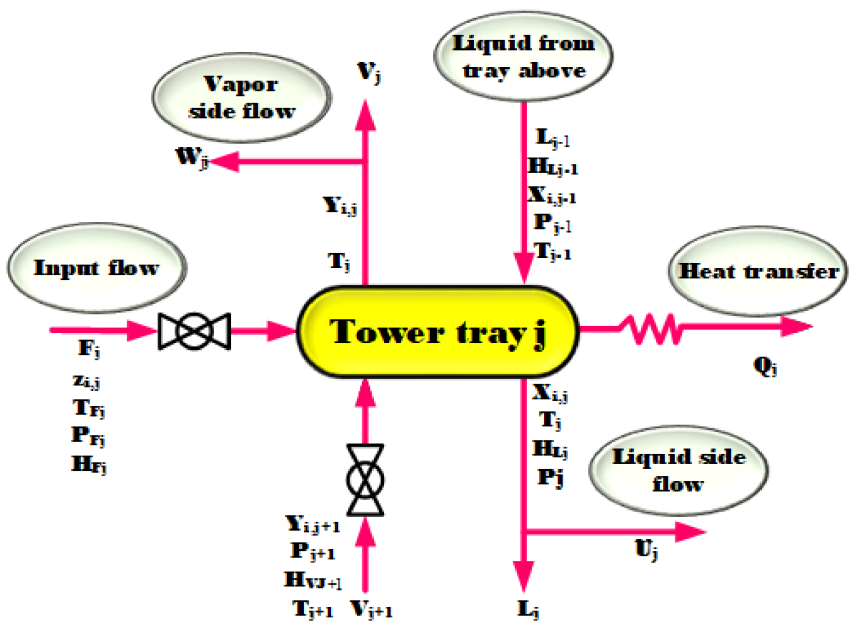

Figure 5. The overall balance in one of the stages of the distillation tower, (modified from [30]).

Regarding Figure 5, MESH equations can be written as follows [30]:

$$
L_{j-1} x_{i, j-1}+V_{j+1} y_{i, j+1}+F_{j} Z_{i, j}-\left(L_{j}+U_{j}\right) x_{i, j}-\left(V_{j}+W_{j}\right) y_{i, j}=0
$$

The balanced equation for each section in a tray of the tower is:

$$
y_{i, j}-k_{i, j} x_{i, j}=0
$$

The sum equation for each tray is:

$$
\begin{aligned}
& \sum_{i=1}^{N C} x_{i, j}-1=0 \\
& \sum_{i=1}^{N C} y_{i, j}-1=0
\end{aligned}
$$

The thermal energy balance equation for each tray is:

$$
\mathrm{L}_{\mathrm{j}-1} \mathrm{H}^{\mathrm{L}}{ }_{\mathrm{j}-1}+\mathrm{V}_{\mathrm{j}+1} \mathrm{H}^{\mathrm{V}}{ }_{\mathrm{j}+1}+\mathrm{F}_{\mathrm{j}} \mathrm{H}_{\mathrm{j}}^{\mathrm{F}}-\left(\mathrm{L}_{\mathrm{j}}+\mathrm{U}_{\mathrm{j}}\right) \mathrm{H}_{\mathrm{j}}^{\mathrm{L}}-\left(\mathrm{V}_{\mathrm{j}}+\mathrm{W}_{\mathrm{j}}\right) \mathrm{H}^{\mathrm{V}}{ }_{\mathrm{j}}-\mathrm{Q}_{\mathrm{j}}=0
$$

In Equation (36), $Q$ is determined based on the heat source with a temperature of $T_{0}$.

\section{Exergy Analysis}

Exergy is the maximum power achievable from a system in its transition to the standard condition by a reversible process. Therefore, exergy can be defined as reversible work. Hence, exergy destruction has a direct relation with entropy production.

$$
\mathrm{Ex}_{\text {destroyed }}=\mathrm{T}_{0} \mathrm{~S}_{\text {gen }} \geq 0
$$


The exergy loss in all real systems has a positive value and is zero for reversible systems. By ignoring nuclear, electrical, potential, kinetic, surface tension, and magnetic energies, the total exergy rate of a system can be calculated as [31]:

$$
\dot{\mathrm{Ex}}=\dot{\mathrm{Ex}} \mathrm{ph}_{\mathrm{p}}+\dot{\mathrm{Ex}} \mathrm{ch}
$$

where $\dot{E x}, \dot{E} x_{p h}$, and $\dot{E x}$ ch are the exergy rate of the stream, the sum of its physical exergies, and the sum of its chemical exergies, achievable by Equations (39) and (40) [32]:

$$
\begin{gathered}
\dot{\mathrm{Ex}} \mathrm{ph}_{\mathrm{p}}=\sum_{\mathrm{i}} \dot{\mathrm{n}}_{\mathrm{i}}\left(\left(\overline{\mathrm{h}}_{\mathrm{i}}-\overline{\mathrm{h}}_{0}\right)-\mathrm{T}_{0}\left(\overline{\mathrm{s}}_{\mathrm{i}}-\overline{\mathrm{s}}_{0}\right)\right) \\
\dot{\mathrm{Ex}} \mathrm{ch}_{\mathrm{n}}=\dot{\mathrm{n}}\left(\sum_{\mathrm{i}} \mathrm{x}_{\mathrm{i}} \overline{\mathrm{ex}}_{\mathrm{i}}^{\mathrm{ch}, 0}+\overline{\mathrm{R}} \mathrm{T}_{0} \sum_{\mathrm{i}} \mathrm{x}_{\mathrm{i}} \ln \left(\mathrm{x}_{\mathrm{i}} \gamma_{\mathrm{i}}\right)\right)
\end{gathered}
$$

$\overline{\mathrm{h}}_{0}$ and $\overline{\mathrm{s}}_{0}$ are enthalpy and entropy at the ambient pressure and temperature. In Equation (39), $\gamma_{i}$ is the activity coefficient of the $i^{\text {th }}$ component that can be more or less than one, and its value for the ideal mixture is zero. The calculation of chemical exergies for nonideal mixtures using Equation (40) is problematic, as the second term in this equation is the Gibbs free energy of different components when forming the mixture in the ambient condition.

Regarding the definition of chemical exergy, all the calculations are performed at ambient temperature. Therefore, $\mathrm{G}$ is the Gibbs free energy in the ambient temperature. Besides, $G^{E}$ is:

$$
\mathrm{G}^{\mathrm{E}}=\mathrm{RT}_{\circ} \sum \mathrm{x}_{\mathrm{i}} \operatorname{Ln} \gamma_{\mathrm{i}}
$$

Adding the same term in each side of Equation (42):

$$
\begin{gathered}
\mathrm{G}^{\mathrm{E}}+\mathrm{RT}_{\circ} \sum \mathrm{x}_{\mathrm{i}} \operatorname{Ln} \mathrm{x}_{\mathrm{i}}=\mathrm{RT}_{\circ} \sum \mathrm{x}_{\mathrm{i}} \operatorname{Ln} \gamma_{\mathrm{i}}+\mathrm{RT}_{\circ} \sum \mathrm{x}_{\mathrm{i}} \operatorname{Ln} \mathrm{x}_{\mathrm{i}}=\mathrm{RT}_{\circ} \sum \mathrm{x}_{\mathrm{i}}\left(\operatorname{Lnx}_{\mathrm{i}}+\operatorname{Ln} \gamma_{\mathrm{i}}\right) \\
=\mathrm{RT}_{\circ} \sum \mathrm{x}_{\mathrm{i}}\left(\operatorname{Ln} \mathrm{x}_{\mathrm{i}} \gamma_{\mathrm{i}}\right)
\end{gathered}
$$

By inserting Equation (42) into Equation (41):

$$
\begin{gathered}
G-\sum x_{i} G_{i}-R T_{\circ} \sum x_{i} L n x_{i}+R T_{\circ} \sum x_{i} \operatorname{Ln} x_{i}=R T_{\circ} \sum x_{i} \operatorname{Ln} x_{i} \gamma_{i} \\
\rightarrow G-\sum x_{i} G_{i}=R T_{\circ} \sum x_{i} \operatorname{Ln} x_{i} \gamma_{i}=\Delta G^{\text {mix }}
\end{gathered}
$$

$\Delta G^{\text {mix }}$ is the change in the Gibbs free energy at ambient temperature. Finally, the chemical exergy equation is converted into Equation (44) [21]:

$$
\dot{\mathrm{Ex}_{\mathrm{ch}}}=\dot{\mathrm{n}}\left(\sum_{\mathrm{i}} \mathrm{x}_{\mathrm{i}} \overline{\mathrm{ex}}_{\mathrm{i}}^{\mathrm{ch}, 0}\right)+\Delta \mathrm{G}^{\mathrm{mix}}
$$

The main objective of the exergy analysis is to find the places in a thermodynamic system where irreversibility occurs and measure them. This analysis helps to promote the systems' efficiency. The exergy balance equation is shown in Equation (45) [21]:

$$
\mathrm{Ex}_{\mathrm{i}}+\mathrm{Ex}_{\mathrm{Qi}}=\mathrm{Ex}_{\mathrm{o}}+\mathrm{Ex}_{\mathrm{Qo}}+\mathrm{W}_{\mathrm{sh}}+\mathrm{I}
$$

Equation (45) is used to calculate the irreversibility or exergy losses. Ex $x_{i}, E_{0}, E_{Q i}$, $E x_{\mathrm{Qo}}, \mathrm{W}_{\mathrm{sh}}$, and I are exergies of inlet and outlet flows, and exergies of inlet and outlet energy streams, axial work, and irreversibility (exergy loss), respectively.

$$
\mathrm{I}_{\mathrm{p}, \mathrm{c}}=\mathrm{Ex}_{\mathrm{i}}-\mathrm{Ex}_{\mathrm{o}}=\sum(\dot{\operatorname{mex}})_{\mathrm{i}}+\mathrm{W}-\sum(\dot{\operatorname{mex}})_{\mathrm{o}}
$$


$\mathrm{Ex}_{\mathrm{i}}$ and $E x_{\mathrm{o}}$ are the irreversibility of the inlet and outlet exergies. The efficiency of pumps and compressors is calculated as follows [21]:

$$
\eta_{\mathrm{p}, \mathrm{c}}=\frac{\sum(\dot{\mathrm{mex}})_{\mathrm{i}}-\sum_{\mathrm{i}}(\dot{\mathrm{mex}})_{\mathrm{o}}}{\mathrm{W}}
$$

The exergy destruction and the efficiency of turbines can be calculated by Equations (48) and (49) [21]:

$$
\begin{gathered}
\mathrm{I}_{\mathrm{T}}=\mathrm{Ex}_{\mathrm{i}}-\mathrm{Ex}_{\mathrm{o}}=\sum(\dot{\mathrm{mex}})_{\mathrm{i}}-\mathrm{W}-\sum_{\mathrm{i}}(\dot{\mathrm{mex}})_{\mathrm{o}} \\
\eta_{\mathrm{t}}=\frac{\mathrm{W}}{\sum(\dot{\mathrm{mex}})_{\mathrm{i}}-\sum_{\mathrm{i}}(\dot{\mathrm{mex}})_{\mathrm{o}}}
\end{gathered}
$$

For heat exchangers, $\mathrm{I}_{\mathrm{HX}}$ and $\eta_{\mathrm{HX}}$ are calculated by [21]:

$$
\begin{gathered}
\mathrm{I}_{\mathrm{HX}}=\mathrm{Ex}_{\mathrm{i}}-\mathrm{Ex}_{\mathrm{o}}=\sum(\dot{\mathrm{mex}})_{\mathrm{i}}-\sum(\dot{\mathrm{mex}})_{\mathrm{o}} \\
\eta_{\mathrm{HX}}=1-\left\{\left[\frac{\sum_{1}^{\mathrm{n}}(\dot{\mathrm{m}} \Delta \mathrm{ex})}{\sum_{1}^{\mathrm{n}}(\dot{\mathrm{m}} \Delta \mathrm{eh})}\right]_{\mathrm{h}}-\left[\frac{\sum_{1}^{\mathrm{n}}(\dot{\mathrm{m}} \Delta \mathrm{ex})}{\sum_{1}^{\mathrm{n}}(\dot{\mathrm{m}} \Delta \mathrm{eh})}\right]_{\mathrm{c}}\right\}
\end{gathered}
$$

For the exergy destruction and its efficiency in throttling valves, Equations (52) and (53) are utilized [21]:

$$
\begin{gathered}
\mathrm{I}_{\mathrm{V}}=\mathrm{Ex}_{\mathrm{i}}-\mathrm{Ex}_{\mathrm{o}}=\sum(\dot{\mathrm{m} \cdot e x})_{\mathrm{i}}-\sum(\dot{\mathrm{m}} \cdot \mathrm{ex})_{\mathrm{o}} \\
\eta_{\mathrm{ex}}=\frac{\mathrm{ex}_{\mathrm{o}}^{\Delta \mathrm{T}}-\mathrm{ex}_{\mathrm{i}}^{\Delta \mathrm{T}}}{\mathrm{ex}_{\mathrm{i}}^{\Delta \mathrm{p}}-\mathrm{ex}_{\mathrm{o}}^{\Delta \mathrm{p}}},\left(e x^{\Delta \mathrm{T}}=\int_{\mathrm{T}}^{\mathrm{T}_{0}} \frac{\mathrm{T}-\mathrm{T}_{0}}{\mathrm{~T}} \mathrm{dh}, \mathrm{ex}^{\mathrm{Ph}}=\mathrm{ex}^{\Delta \mathrm{T}}+\mathrm{ex}^{\Delta \mathrm{T}}\right)
\end{gathered}
$$

In distillation columns (towers) for the calculation of exergy destruction and exergy efficiency, the following equations are employed [21]:

$$
\begin{gathered}
\mathrm{I}_{\text {Column }}=\mathrm{Ex}_{\mathrm{i}}-\mathrm{Ex}_{\mathrm{o}}=\sum(\dot{\mathrm{m} \cdot e x})_{\mathrm{i}}+\mathrm{Ex}_{\text {Reb }}^{\mathrm{Q}}-\mathrm{Ex}_{\text {Con }}^{\mathrm{Q}}-\sum(\dot{\mathrm{m}} \cdot \mathrm{ex})_{\mathrm{o}} \\
\eta_{\mathrm{ex}}=\frac{\mathrm{Ex}_{\mathrm{Con}}^{\mathrm{Q}}+\sum(\dot{\mathrm{m}} \cdot \mathrm{ex})_{\mathrm{o}}}{\sum(\dot{\mathrm{m}} \cdot \mathrm{ex})_{\mathrm{i}}+\mathrm{Ex}_{\mathrm{Reb}}^{\mathrm{Q}}}
\end{gathered}
$$

$I_{\text {Reactor }}$ and $\eta_{\text {ex }}$ are the exergy destruction and exergy efficiency of the methanol reactor achievable by Equations (56) and (57) [21]:

$$
\begin{gathered}
\mathrm{I}_{\text {Reactor }}=\mathrm{Ex}_{\mathrm{i}}-\mathrm{Ex}_{\mathrm{o}}=\sum(\dot{\mathrm{m}} \cdot \mathrm{ex})_{\mathrm{i}}-\mathrm{Ex}_{\text {out }}^{\mathrm{Q}}-\sum(\dot{\mathrm{m}} \cdot \mathrm{ex})_{\mathrm{o}} \\
\eta_{\mathrm{ex}}=\frac{\mathrm{Ex}_{\text {out }}^{\mathrm{Q}}}{\sum(\dot{\mathrm{m} \cdot \mathrm{ex}})_{\mathrm{i}}-\sum(\dot{\mathrm{m}} \cdot \mathrm{ex})_{\mathrm{o}}}
\end{gathered}
$$

For parabolic solar troughs, exergy efficiency and exergy destruction are calculated as follows [21]:

$$
\begin{gathered}
\mathrm{I}_{\text {Collector }}=\mathrm{Ex}_{\mathrm{i}}-\mathrm{Ex}_{\mathrm{o}}=\sum(\dot{\mathrm{m}} \cdot \mathrm{ex})_{\mathrm{i}}-\mathrm{Ex}_{\mathrm{out}}^{\mathrm{Q}}-\sum(\dot{\mathrm{m}} \cdot \mathrm{ex})_{\mathrm{o}} \\
\mathrm{Ex}_{\text {out }}^{\mathrm{Q}}=\left[1-\frac{4}{3} \frac{\mathrm{T}_{\mathrm{a}}}{\mathrm{T}_{\mathrm{s}}}(1-0.28 \ln \mathrm{f})\right] \times \dot{\mathrm{Q}}_{\text {in }} \\
\eta_{\mathrm{ex}}=\frac{\sum(\dot{\mathrm{m}} \cdot \mathrm{ex})_{\mathrm{i}}-\sum(\dot{\mathrm{m}} \cdot \mathrm{ex})_{\mathrm{o}}}{\mathrm{Ex}_{\text {out }}^{\mathrm{Q}}}
\end{gathered}
$$




\section{Results and Discussion}

In this paper, an integrated structure for the cogeneration of liquid methanol, power, and heat is developed. The weather condition of Bushehr city is considered for the model of parabolic solar troughs. The cryogenic purification cycle provides $88.05 \%$ molar hydrogen from the $55 \%$ molar feed of crude hydrogen. This cycle receives $19.62 \mathrm{~kW}$ of lowtemperature cooling from the absorption-compression refrigeration cycle and $19.62 \mathrm{~kW}$ of low-temperature cooling from liquid nitrogen to produce side products. These side products include $1123 \mathrm{~kg} / \mathrm{h}$ of low-pressure fuel ( $86.81 \%$ molar methane) and $54.99 \mathrm{~kg} / \mathrm{h}$ of high-pressure fuel (95.08\% molar methane). The residual outlet of the cycle consists of $871.1 \mathrm{~kg} / \mathrm{h}$ of aromatic compounds. The purified hydrogen and $\mathrm{CO}_{2}$ enter the methanol production cycle to produce $4741 \mathrm{~kg} / \mathrm{h}$ of liquid methanol, easy to store or transport to remote areas. For supplying thermal power in this cycle, parabolic solar troughs and auxiliary boilers are designed. The ACRC and regenerative ORC recover the heat of the exothermic reaction in the methanol reactor. The ACRC provides $29.97 \mathrm{~kW}$ of cooling at $-42.07{ }^{\circ} \mathrm{C}$ for the hydrogen purification cycle by receiving $49.05 \mathrm{~kW}$ of heat. The regenerative ORC produces $475 \mathrm{~kW}$ of net electrical power from its $2418 \mathrm{~kW}$ input thermal power. Plots of $\mathrm{P}-\mathrm{H}$ and T-S corresponding to the regenerative ORC are shown in Figure $6 \mathrm{a}, \mathrm{b}$, providing information regarding the vapor fraction of the stream and places with irreversibility and entropy production.

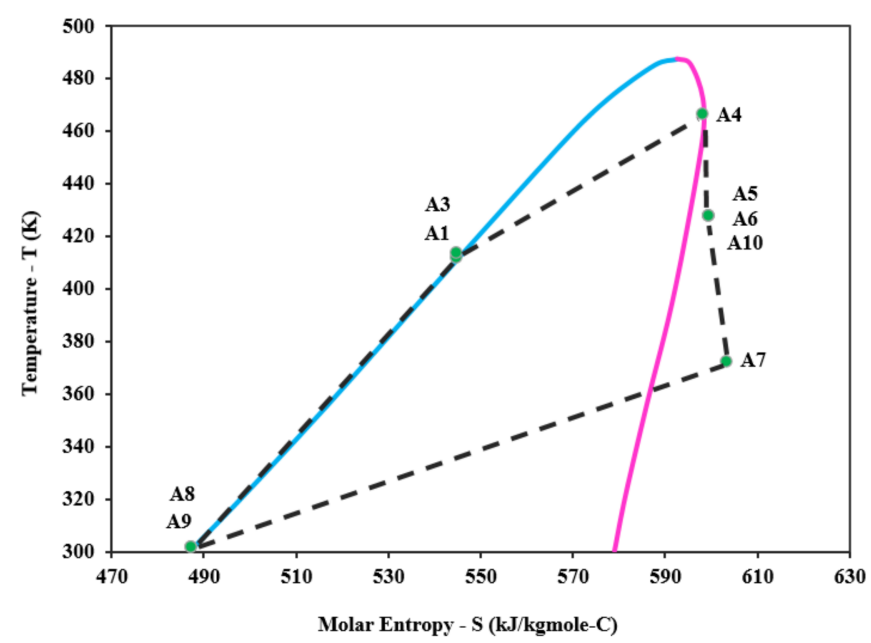

(a)

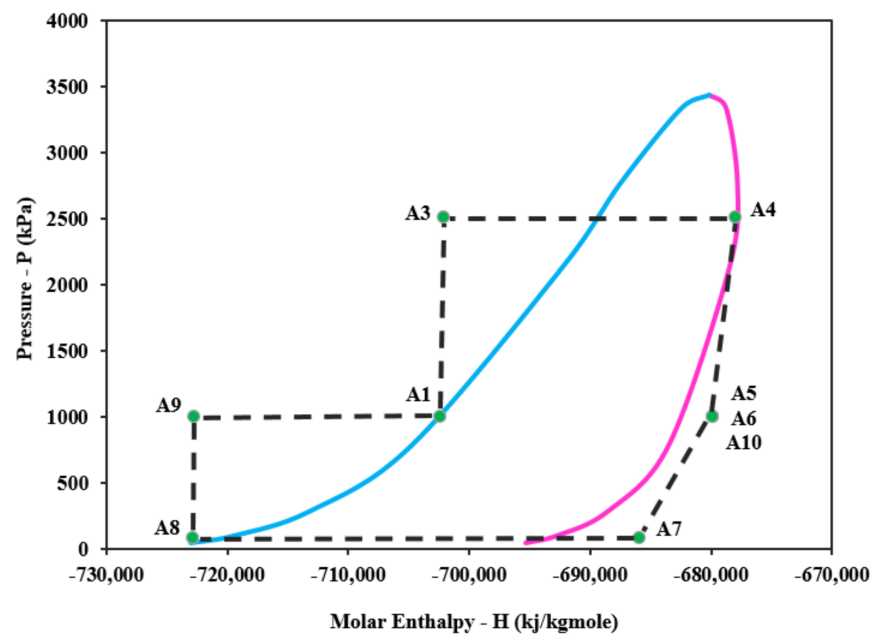

(b)

Figure 6. The organic Rankine power generation cycle: (a) T-S diagram; (b) P-H diagram.

The plug flow reactor is used for methanol production modeled in Aspen HYSYS V10.0 software. This reactor produces $2493 \mathrm{~kW}$ of heat at $200{ }^{\circ} \mathrm{C}$. Parabolic solar troughs are utilized to supply the required $3435 \mathrm{~kW}$ of thermal power in the methanol distillation tower for the separation of water and liquid methanol. As the intensity and direction of the sun are not stable, the periodic nature of the amount of the heat suppliable by the solar collectors necessitates the use of an auxiliary boiler to ensure the constant thermal power. Parabolic solar troughs are modeled using MATLAB V10.0 m-file code, each having a $6.1 \mathrm{~m}$ length and $2.3 \mathrm{~m}$ width. The oil stream containing $24.62 \%$ molar Biphenyl and $75.38 \%$ molar dipH-Ether is used for the heat transfer from the solar collectors to the distillation tower. The thermal and optic efficiencies, outlet temperature from the collectors, and useful thermal power at $12: 00 \mathrm{O}^{\prime}$ clock are $42.37 \%, 24.08 \%, 184.9^{\circ} \mathrm{C}$, and $3422.8 \mathrm{~kW}$, respectively. An auxiliary boiler supplies the remaining required heat $(12.2 \mathrm{~kW})$. The results show that the energy efficiencies of the regenerative ORC, the methanol production cycle, the total thermal efficiency of the integrated structure, and the COP of the ACRC are $19.46 \%, 60.91 \%$, $78.014 \%$, and 0.3031 , respectively. The results of energy, exergy, and sensitivity analyses of the integrated structure are as follows. Validations of the developed integrated structure 
are available in Appendix A. Thermodynamic characteristics of streams are provided in Table A4.

\subsection{Energy Analysis Results}

The required information for each subsystem and cycle is extracted from data in industrial patents and scientific references. Table 2 shows the operational condition of equipment used in the proposed integrated structure. The minimum temperature difference between the hot and cold curves in heat exchangers $\left(\Delta \mathrm{T}_{\min }\right)$ is considered as the output parameter. It is the main factor contributing to the heat transfer between hot and cold sections. The refrigeration cycles' integration in the present study is provided by the process core in the form of cold and hot composite curves. The pinch technology can modify the energy consumption and determine the required utility by using its key tools of composite curves (CC) and grand composite curves (GCC). Figure 7a-c show composite curves of three multi-stream heat exchangers of $\mathrm{HX} 1, \mathrm{HX} 3$, and $\mathrm{HX} 4$. In heat exchangers in which a single-component refrigerant is used $\left(\mathrm{CO}_{2}\right.$ in the $\mathrm{HX} 1$ exchanger and $\mathrm{N}_{2}$ in the HX4 exchanger), the distance between hot and cold curves is more than that of the heat exchanger with a multi-component refrigerant. A good matching between hot and cold curves in the heat exchanger with the multi-component refrigerant is noticeable as the $\Delta \mathrm{T}_{\min }$ value decreases, utilities used in the structure decrease, and the area required for heat transfer increases.

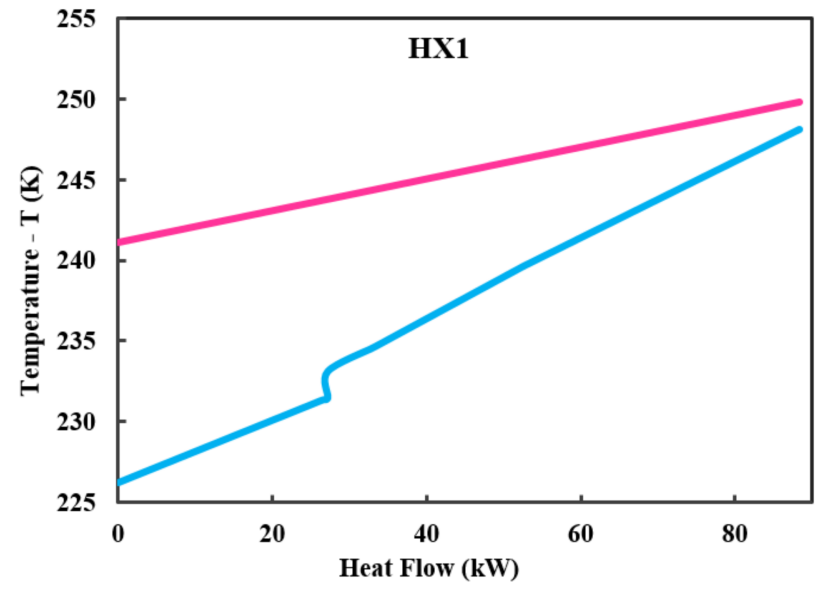

(a)

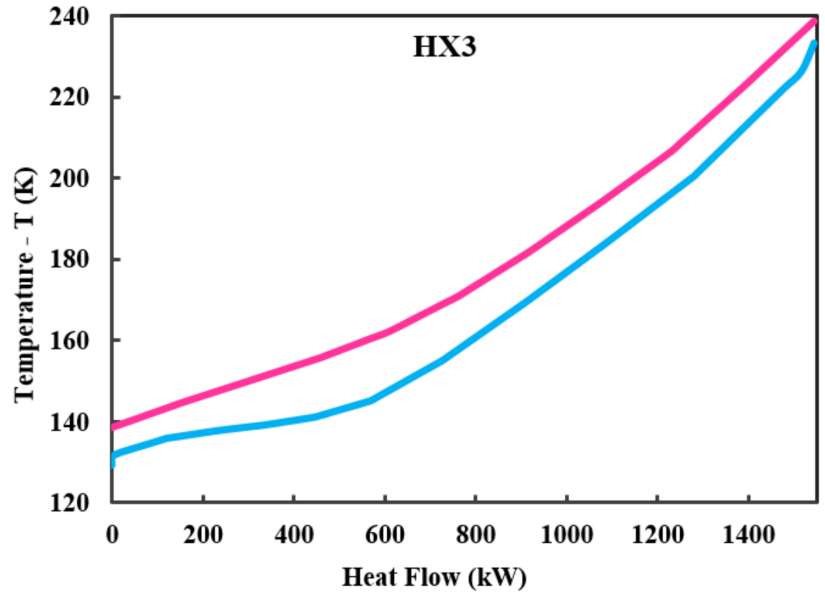

(b)

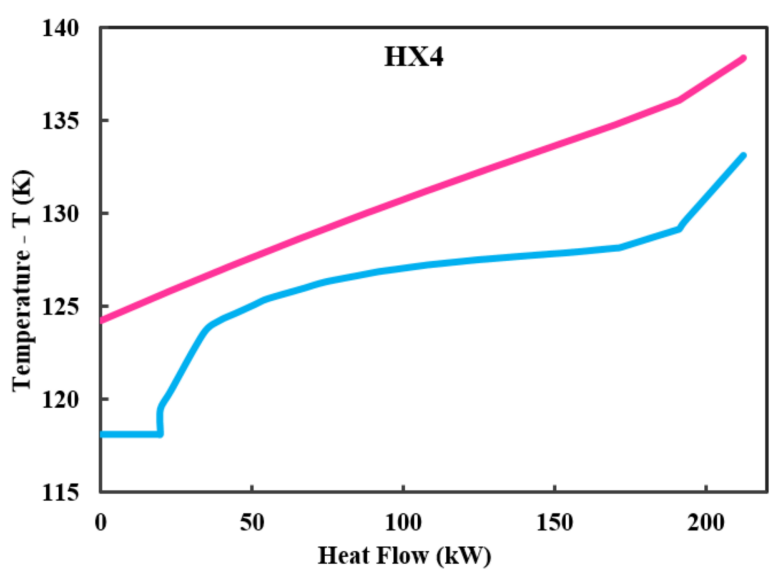

(c)

Figure 7. Hot (pink) and cold (blue) composite curves for (a) HX1, (b) HX3, and (c) HX4. 
Table 2. Equipment major specifications.

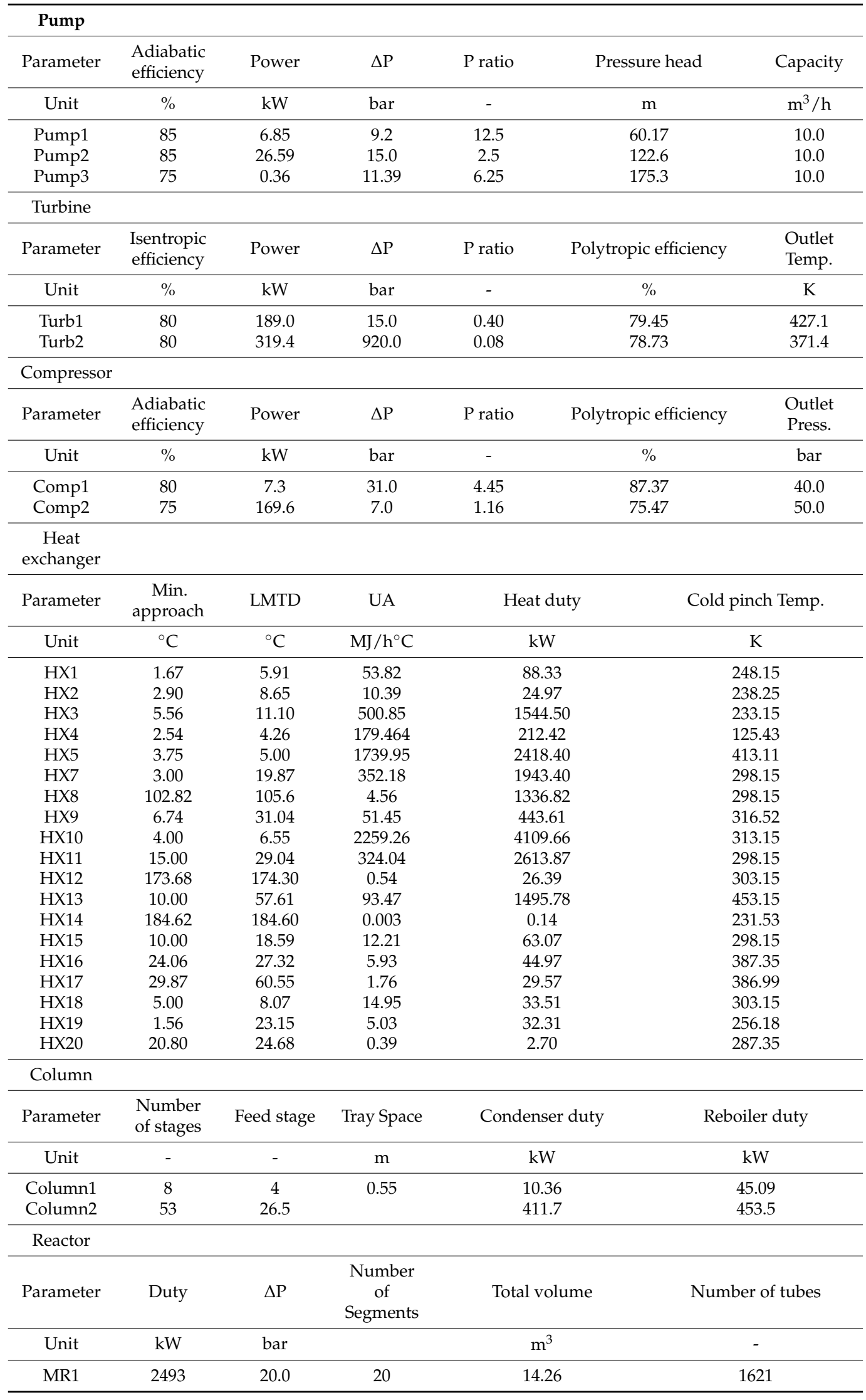


Figure 8a-c show the grand composite curves for the HX1, HX3, and HX4 exchangers. In this paper, Aspen HYSYS V10.0 software is used to determine the pinch point, and MATLAB V10.0 software in connection with Aspen HYSYS V10.0 is used for drawing the composite curves and grand composite curves.

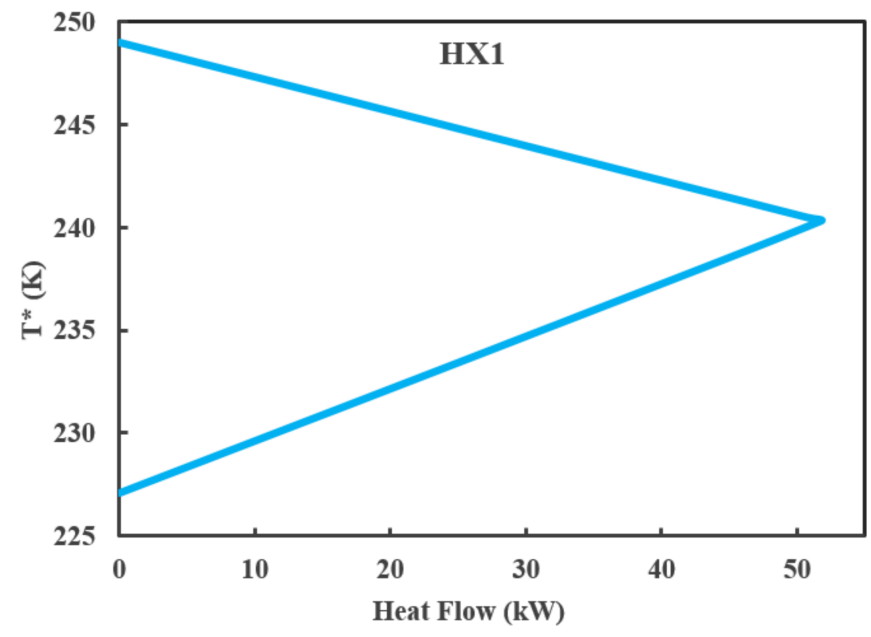

(a)

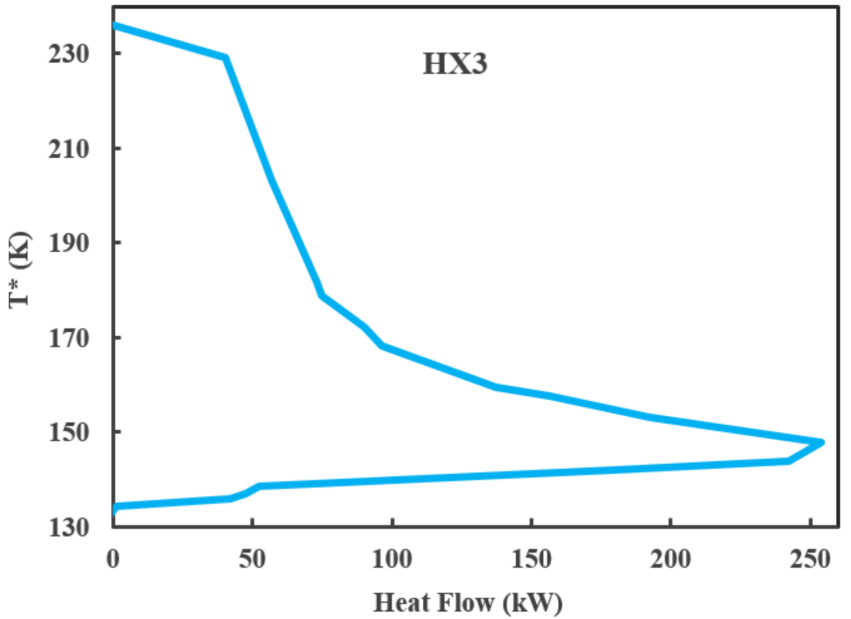

(b)

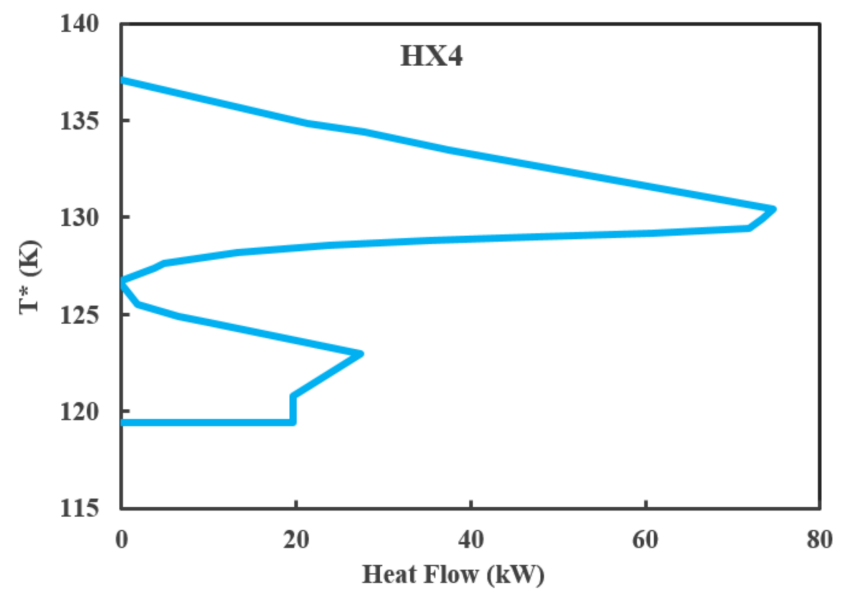

(c)

Figure 8. Grand composite curves (GCC) for (a) HX1, (b) HX3, and (c) HX4.

\subsection{Exergy Analysis Results}

Exergy analysis is performed using Aspen HYSYS V10.0 software and MATLAB V10.0 $\mathrm{m}$-file programming. The functions used to link HYSYS V10.0 software and MATLAB V10.0 programming are available in the Supplementary Materials. The first step in the exergy analysis is the exergy calculation of streams in the processes, including the exergy of each stream and its exergy loss. Using exergy balance for each piece of equipment, its exergy destruction and exergy efficiency can be calculated. The inlet, outlet, and destructed exergies in each piece of equipment are shown in Table 3. It shows that throttling valves have lower exergy efficiencies than other equipment. The reason for using these valves in refrigeration processes is to decrease the refrigerant's temperature by lowering its pressure. The reduced temperature facilitates the cooling of hot sources in the process. Therefore, the exergy efficiency in throttling valves can be defined as the exergy difference related to providing cooling to the exergy difference related to the pressure decrease. As these valves have lower exergy destruction than other equipment, their contribution to the total exergy destruction is insignificant. Due to high levels of heat transfers in heat exchangers, they produce considerable irreversibility. However, as shown in Table 3, heat exchangers 
have higher exergy efficiencies than other equipment. Therefore, for the performance comparison of equipment used, both their irreversibility and exergy efficiency parameters are considered. Figure 9 illustrates the share of each piece of equipment in the total exergy destruction, with the parabolic solar trough taking the lion's share of $34 \%$, followed by heat exchangers with $30 \%$ and mixers with $19 \%$ of the total share. Among heat exchangers, the maximum share of exergy destruction belongs to the HX6 and HX8 exchangers, with $50 \%$ and $11 \%$, respectively. Based on the exergy analysis, the total exergy efficiency of the integrated structure and its irreversibility are $89.45 \%$ and $16.89 \mathrm{MW}$, respectively.

Table 3. Inlet and outlet exergies, exergy efficiency, and exergy destruction of each piece of equipment.

\begin{tabular}{|c|c|c|c|c|c|c|c|c|c|}
\hline Item & $\begin{array}{l}\text { Inlet } \\
\text { Exergy }\end{array}$ & $\begin{array}{l}\text { Outlet } \\
\text { Exergy }\end{array}$ & $\begin{array}{c}\text { Exergy } \\
\text { Destruc- } \\
\text { tion }\end{array}$ & $\begin{array}{l}\text { Exergy } \\
\text { Effi- } \\
\text { ciency }\end{array}$ & Item & $\begin{array}{l}\text { Inlet } \\
\text { Exergy }\end{array}$ & $\begin{array}{l}\text { Outlet } \\
\text { Exergy }\end{array}$ & $\begin{array}{c}\text { Exergy } \\
\text { Destruc- } \\
\text { tion }\end{array}$ & $\begin{array}{c}\text { Exergy } \\
\text { Effi- } \\
\text { ciency }\end{array}$ \\
\hline & $\mathrm{kW}$ & $\mathrm{kW}$ & $\mathrm{kW}$ & $\mathrm{kW}$ & & $\mathrm{kW}$ & $\mathrm{kW}$ & $\mathrm{kW}$ & $\mathrm{kW}$ \\
\hline HX1 & 312,897 & 312,893 & 3.84 & 95.65 & Pump2 & 16,415 & 16,411 & 3.43 & 87.11 \\
\hline HX2 & 156,642 & 156,641 & 1.17 & 95.33 & Pump3 & 1121 & 1121 & 0.09 & 75.82 \\
\hline HX3 & 293,351 & 293,156 & 194.7 & 87.39 & Sep1 & 156,589 & 156,589 & 0.00 & 100 \\
\hline HX4 & 136,878 & 136,860 & 18.11 & 91.48 & Sep2 & 147,260 & 147,260 & 0.00 & 100 \\
\hline HX5 & 809,672 & 809,614 & 57.37 & 97.63 & Sep3 & 68,5211 & 68,521 & 0.00 & 100 \\
\hline HX6 & 795,551 & 793,967 & 1583 & 99.80 & Sep4 & 49,070 & 49,016 & 54.12 & 100 \\
\hline HX7 & 37,832 & 37,742 & 89.95 & 95.37 & Tank1 & 27,848 & 27,848 & 0.00 & 100 \\
\hline HX8 & 71,211 & 70,854 & 356.5 & 73.33 & TEE1 & 17,013 & 17,013 & 0.00 & 100 \\
\hline HX9 & 28,754 & 28,710 & 43.79 & 90.13 & TEE2 & 1121 & 1121 & 0.00 & 100 \\
\hline HX10 & 596,219 & 596,044 & 174.6 & 95.75 & MIX1 & 16,512 & 16,388 & 123.8 & 99.25 \\
\hline HX11 & 552,948 & 552,734 & 213.7 & 91.82 & MIX2 & 1126 & 1125 & 0.50 & 99.96 \\
\hline HX12 & 52,103 & 52,093 & 9.56 & 63.76 & $\mathrm{~T} 1$ * & 1331 & 1146 & 184.2 & 86.16 \\
\hline HX13 & 597,921 & 597,608 & 313.2 & 79.06 & $\mathrm{~T} 2$ ** & 29,422 & 29,262 & 1076 & 99.45 \\
\hline HX14 & 844,348 & 844,348 & 0.08 & 43.03 & V1 & 10,437 & 10,436 & 1.01 & 78.94 \\
\hline HX15 & 3026 & 30,221 & 4.06 & 93.56 & V3 & 68,267 & 68,250 & 17.73 & 73.69 \\
\hline HX16 & 1251 & 1249 & 2.21 & 95.09 & V4 & 16,126 & 16,116 & 10.54 & 69.17 \\
\hline HX17 & 792,827 & 792,823 & 3.70 & 87.49 & V5 & 59.47 & 58.82 & 0.65 & 64.89 \\
\hline HX18 & 1069 & 1069 & 0.08 & 99.77 & V6 & 563.7 & 563.4 & 0.34 & 72.12 \\
\hline HX19 & 621 & 617 & 3.83 & 88.16 & V7 & 568.6 & 568.4 & 0.19 & 75.24 \\
\hline HX20 & 1121 & 1121 & 0.27 & 89.91 & MR1 & 51,244 & 51,108 & 135.9 & 87.16 \\
\hline Turb1 & 17,235 & 17,202 & 33.11 & 85.09 & HE1 & 156,746 & 156,564 & 181.6 & 99.88 \\
\hline Turb2 & 17,235 & 17,202 & 33.11 & 85.09 & $\mathrm{HX} 21$ & 793,294 & 793,191 & 102.2 & 99.99 \\
\hline Comp1 & 65.33 & 51.58 & 0.94 & 87.18 & Collec. & $3,098,312$ & $3,094,735$ & 3577 & 47.34 \\
\hline Comp2 & 51,281 & 51,254 & 26.75 & 84.23 & MIX3 & 52,815 & 50,947 & 1868 & 96.46 \\
\hline Pump1 & 8432 & 8431 & 1.35 & 80.26 & V2 & 78,992 & 78,947 & 45.16 & 77.20 \\
\hline
\end{tabular}

* Ammonia-water distillation tower. ${ }^{* *}$ Methanol distillation tower.

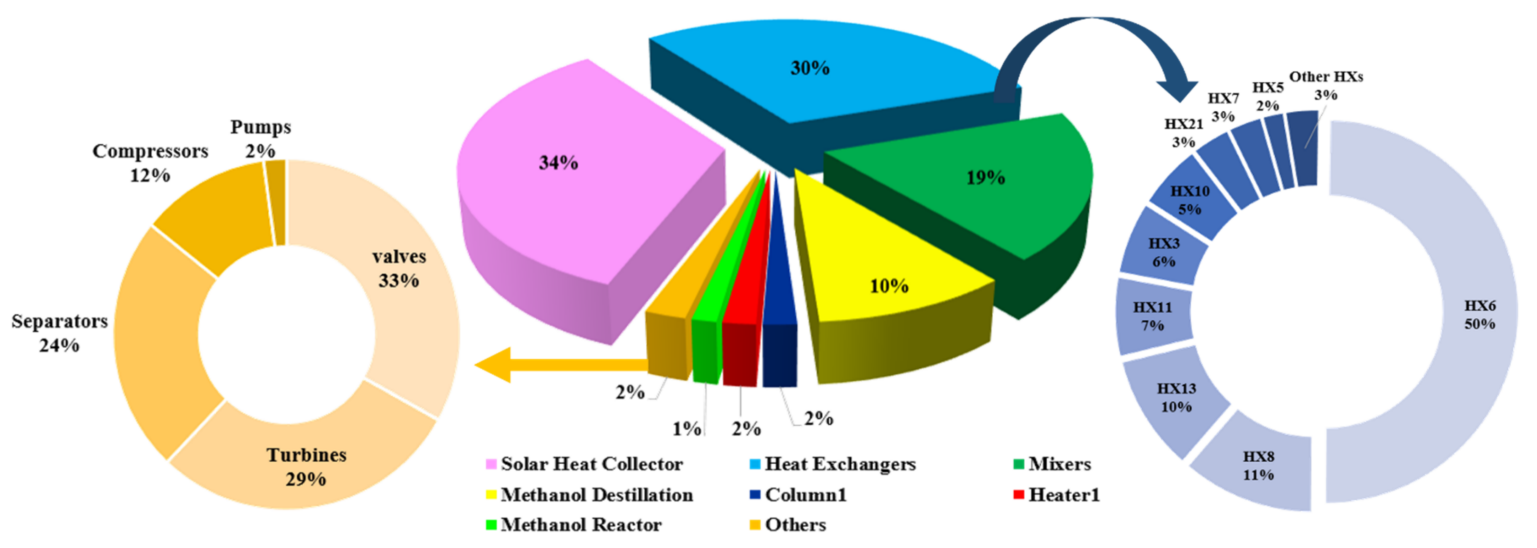

Figure 9. The share of each piece of equipment in the total exergy destruction.

\subsection{Sensitivity Analysis Results}

One of the most effective methods for helping the optimization of a thermodynamic structure is sensitivity analysis. This method assesses the influence of operational variables on the structure's important parameters. Operational variables include temperature, pressure, flow rate, and composition of the streams. By tracing the feedback of the structure to the changes in operational variables, the reaction of the integrated structure and its sensitivity to each alteration could be analyzed. Here, the reaction of the structure to the changes in variables in the most influential streams are presented. 


\subsubsection{Changing the Temperature of Stream D17}

The most important stream in the purification cycle is stream D17. The temperature increase in this stream directly relates to the amount of produced vapor (stream D18), resulting in a decline in hydrogen purity. Therefore, a temperature increase in stream D17 leads to an increase in the methane content of the feed stream $\mathrm{C} 1$ in the methanol production cycle. Considering that the flow rate of $\mathrm{CO}_{2}$ remains unchanged, the methanol production capacity, the heat produced in the methanol reactor, and the thermal power required in the methanol distillation tower will decline. Similarly, the total efficiency and the efficiency of the methanol production cycle will decrease. Figure 10 demonstrates the changes in the main system parameters with the changes in stream D17's temperature. Figure 10a,b show that by increasing the temperature of stream D17 from -149 to $-139{ }^{\circ} \mathrm{C}$, the produced heat in the methanol reactor, required heat in the distillation tower, the efficiency of the integrated structure, and the methanol production rate decrease to $2485 \mathrm{~kW}$, $3420 \mathrm{~kW}, 70.45 \%$, and $4719.6 \mathrm{~kg} / \mathrm{h}$, respectively. Based on the results from Figure 10c, with a temperature decrease in stream D17, the wasted heat and produced methanol decrease, resulting in a decline in the thermal efficiency of the methanol production cycle to $49.77 \%$. Besides, this temperature decrease leads to a growth in exergy destruction to $17.04 \mathrm{MW}$. The main reason for this phenomenon is the increase in the pinch temperature in the HX4 exchanger and the reduction in the production rate.

\subsubsection{Changing the Hydrogen Fraction of Inlet Feed in the Hydrogen Purification Cycle}

The changes in the main parameters of the integrated structure with the changes in the hydrogen fraction of inlet feed in the hydrogen purification cycle are shown in Figure 11. The main parameters here include methanol production rate, exergy efficiency of the integrated structure, wasted heat in the methanol reactor, and solar collectors' thermal power production. A rise in the hydrogen fraction of crude feed gas leads to an increase in hydrogen purity entering the methanol production cycle. Considering that the cooling supplied by nitrogen refrigeration remains unchanged, the fractions of methane and nitrogen in the outlet stream increase, resulting in a decrease in the thermal value. Thus, considering that the flow rate of $\mathrm{CO}_{2}$ is constant, the wasted heat in the methanol reactor and methanol production rate decline. Figure 11a,b show that when the hydrogen purity in the feed gas increases from 55\% to $80 \%$ molar, the exergy efficiency, methanol production rate, wasted heat in the methanol reactor, and the thermal power production by solar collectors decrease to $86.05 \%, 4487 \mathrm{~kg} / \mathrm{h}, 2431.7 \mathrm{~kW}$, and $3261.8 \mathrm{~kW}$, respectively. The increase in the hydrogen purity in the feed gas leads to decreases in the thermal efficiency of the integrated structure to $25.95 \%$ and total exergy destruction to $25.41 \mathrm{MW}$, as shown in Figure 11c.

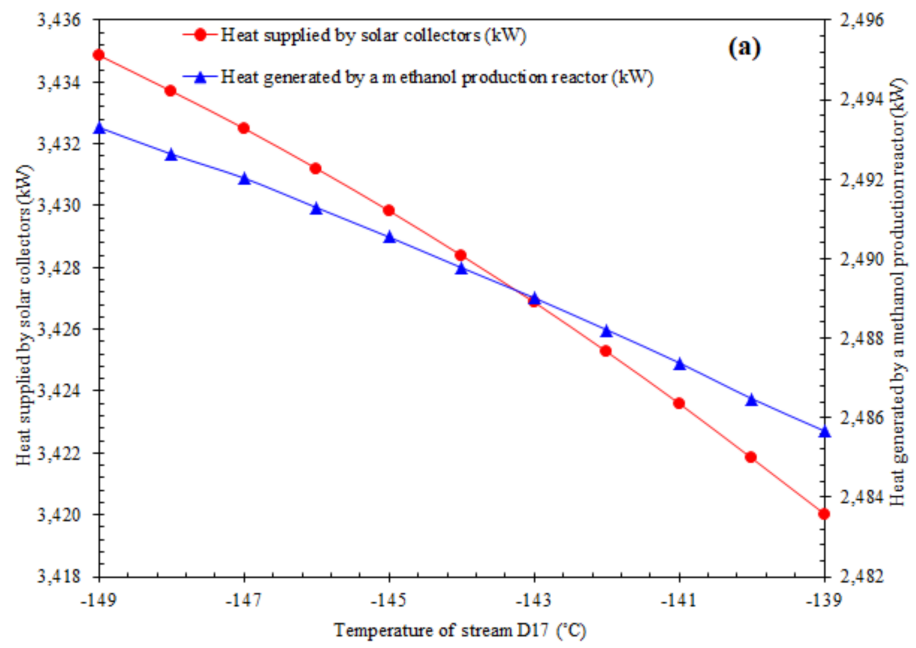

Figure 10. Cont. 

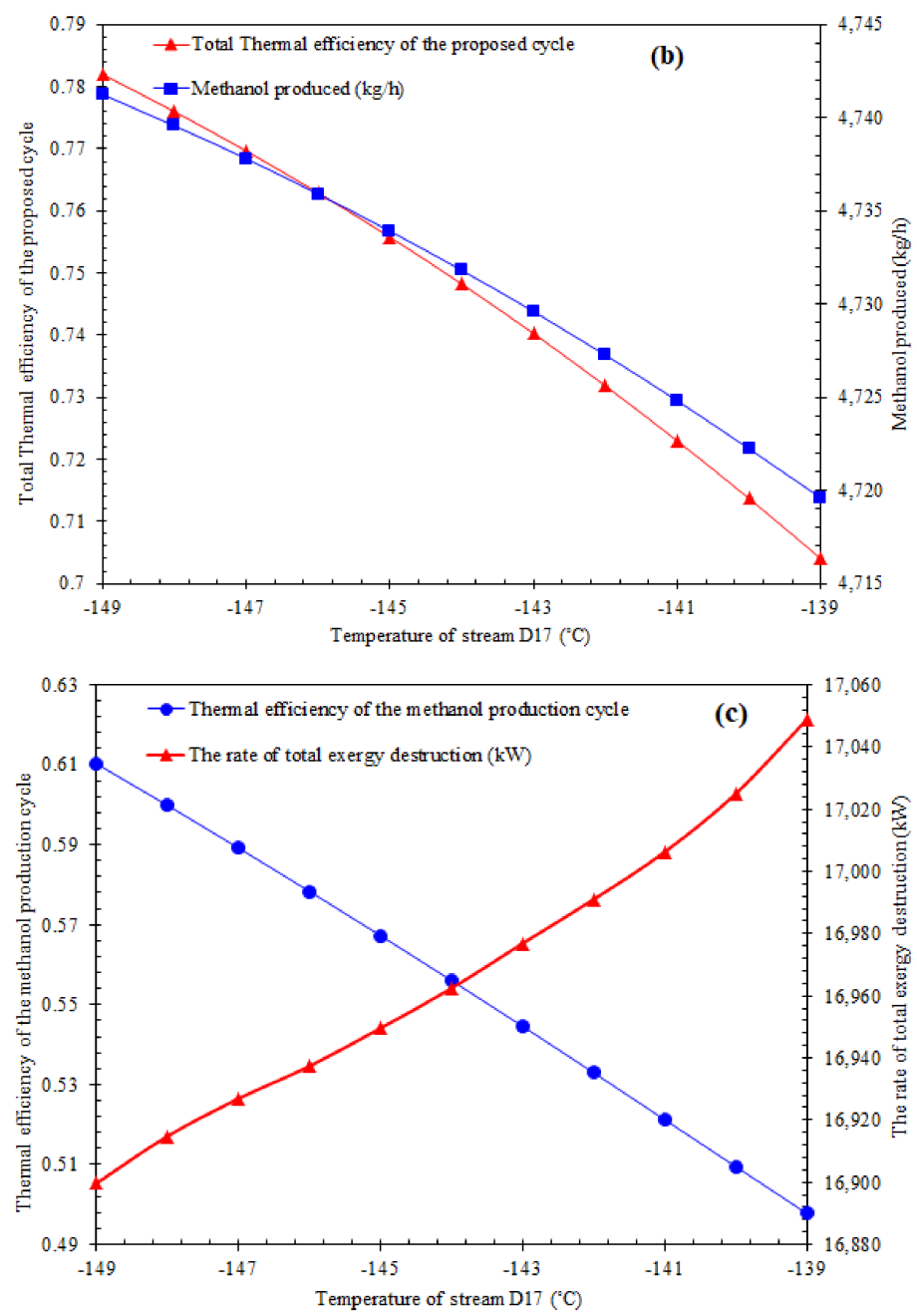

Figure 10. The influence of changes in stream D17's temperature on principal output parameters: (a) The influence of changes in stream D17's temperature on heat supplied by parabolic solar troughs and heat produced by the methanol reactor; (b) The influence of changes in stream D17's temperature on total thermal efficiency and the methanol production rate; (c) The influence of changes in stream D17's temperature on the thermal efficiency of the methanol production cycle and total exergy destruction.

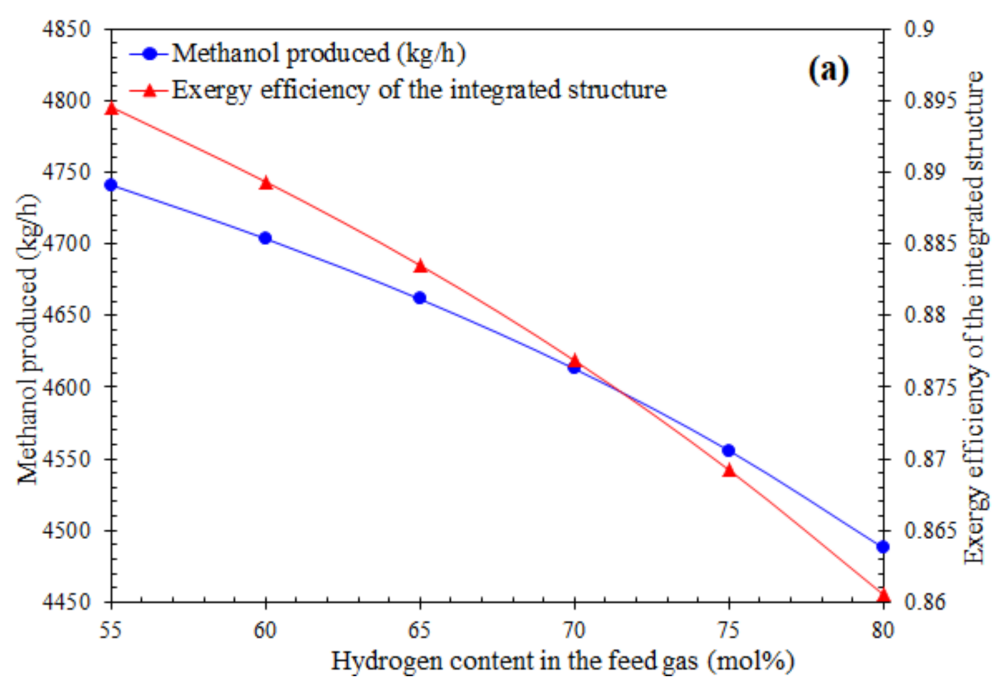

Figure 11. Cont. 

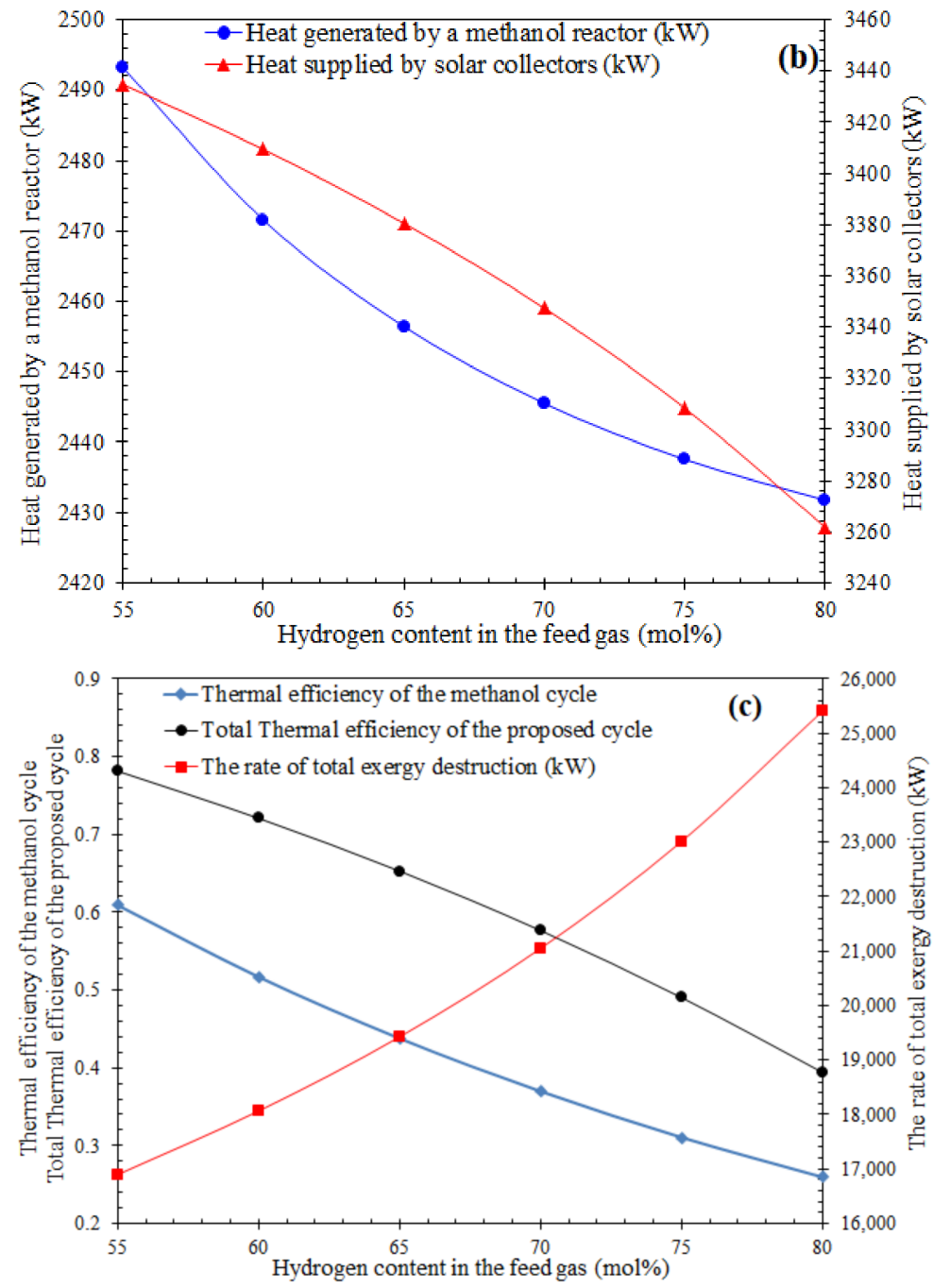

Figure 11. The influence of the changes of the hydrogen content of crude feed gas on main outcome parameters: (a) The influence of the changes of the hydrogen content of crude feed gas on the methanol production rate and total exergy efficiency; (b) The influence of the changes of the hydrogen content of crude feed gas on heat generated by the methanol production reactor and heat supplied by solar collectors; (c) The influence of the changes of the hydrogen content of crude feed gas on total thermal efficiency and thermal efficiency of the methanol production cycle-total exergy destruction.

\subsubsection{Changing the Flow Rate of $\mathrm{CO}_{2}$ in the Methanol Production Cycle}

Considering that the hydrogen fraction of the feed gas remains constant, with an increase in the flow rate of $\mathrm{CO}_{2}$, the wasted heat in the methanol reactor and the methanol production rate increase. Figure 12 shows the influence of this change in the main parameters of the integrated structure. Figure 12a,b show that the growth in the $\mathrm{CO}_{2}$ flow rate from 5000 to $9000 \mathrm{~kg} / \mathrm{h}$ results in increases in the methanol production rate, the thermal efficiency of the integrated structure, the thermal efficiency of the methanol production cycle, and wasted heat in the methanol reactor to $5975.8 \mathrm{~kg} / \mathrm{h}, 82.30 \%, 73.41 \%$, and $3073 \mathrm{~kW}$, respectively. As a considerable part of the total exergy destruction occurs in parabolic solar troughs, with the increase in the required thermal power in the reboiler of the methanol distillation tower, exergy efficiency declines, and exergy destruction increases. 

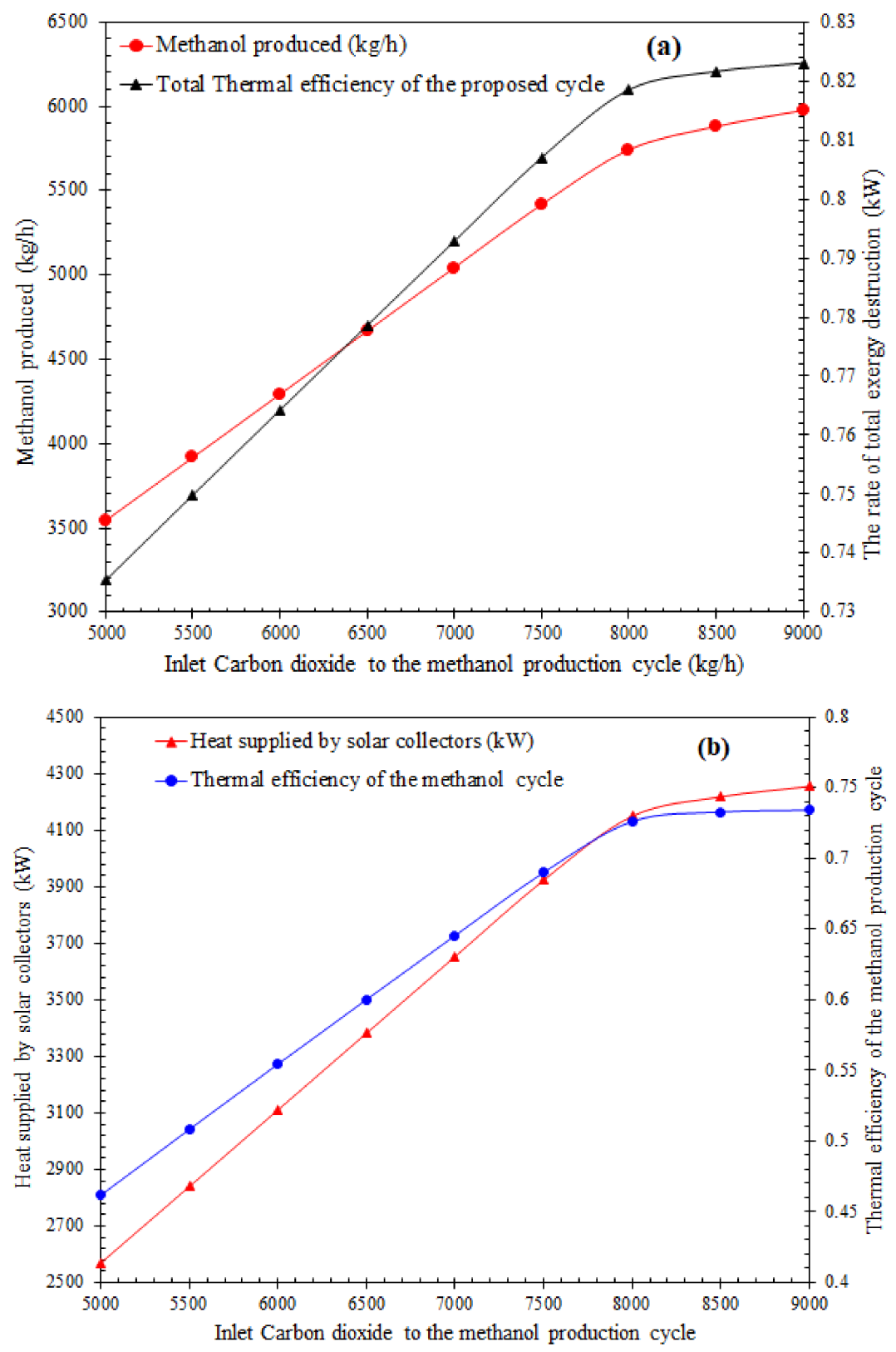

Figure 12. The effect of the changes of the $\mathrm{CO}_{2}$ flow rate on main output parameters: (a) The influence of the changes of the $\mathrm{CO}_{2}$ flow rate on the methanol production rate and total exergy destruction; (b) The influence of the changes of the $\mathrm{CO}_{2}$ flow rate on heat supplied by solar collectors and the thermal efficiency of the methanol production cycle.

The results show that decreasing the flow temperature of D17 and the hydrogen content in the feed gas and increasing the carbon dioxide content entering the methanol production system leads to an increase in the thermal efficiency of the proposed integrated structure and the heat supplied by solar collectors.

\section{Conclusions}

Cogeneration systems in integrated structures increase the efficiency and decrease the equipment in energy systems compared to when each subsystem works separately. This paper proposed a novel system for the cogeneration of liquid methanol, electricity, and hot water. In this integrated structure, hydrogen purification, methanol production, Organic Rankine, absorption-compression cycles, and solar collectors were used. Energy, exergy, 
and sensitivity analyses were employed for the evaluation of the structure, leading to the following results:

1. This integrated structure received $10,000 \mathrm{~kg} / \mathrm{h}$ of crude hydrogen, $6598 \mathrm{~kg} / \mathrm{h}$ of carbon dioxide, and $19.62 \mathrm{~kW}$ of cooling from liquid nitrogen, $3435 \mathrm{~kW}$ of thermal power from parabolic solar troughs, and produced $4741 \mathrm{~kg} / \mathrm{h}$ of liquid methanol, $35.73 \mathrm{ton} / \mathrm{h}$ of hot water, and $297.7 \mathrm{~kW}$ of net electrical power. The side products of this process include low-pressure and high-pressure fuel gases and aromatic compounds. The ORC absorbed the wasted heat in the methanol reactor to produce $475 \mathrm{~kW}$ power and the ACRC to supply $24.97 \mathrm{~kW}$ cooling for the hydrogen purification cycle. The thermal efficiencies of the integrated structure, the liquid methanol production cycle, and the ORC were $78.14 \%, 19.64 \%$, and $60.91 \%$, respectively. The COP of the ACRC was calculated to be $78.14 \%$. The results proved that $98.08 \%$ of the hydrogen was extracted from the crude feed in the purification cycle.

2. The exergy analysis showed that the integrated structure's exergy efficiency and exergy destructions were $89.45 \%$ and $16.89 \mathrm{MW}$, with $6.51 \mathrm{MW}$ being considered as the total exergy loss. Despite the considerably high exergy losses in heat exchangers, their exergy efficiencies were higher than other equipment. Besides, throttling valves have low exergy efficiencies and a minor share in total exergy destruction. The previously mentioned design principles are the main reason for the integrated structure's high efficiency. Thus, no revision or correction is required for the structure.

3. The sensitivity investigation indicated that the thermal efficiency of the methanol production cycle and exergy efficiency of the integrated structure decreased by up to $25.95 \%$ and $86.05 \%$, respectively, when the feed gas's hydrogen content increased from $55 \mathrm{~mol} \%$ to $80 \mathrm{~mol} \%$. The thermal efficiency of the proposed cycle and productivity of the methanol increased by up to $82.30 \%$ and $5975 \mathrm{~kg} / \mathrm{h}$, respectively, with the increase of carbon dioxide composition in the methanol production cycle from 5000 to $9000 \mathrm{~kg} / \mathrm{h}$.

4. For future work, advanced exergoeconomic and environmental analyses can be implemented to decrease economic costs and carbon dioxide emissions. Additionally, it is possible to use multiple compositions instead of a carbon dioxide refrigerant in the refrigeration cycle and evaluate its effect on the main parameters of the integrated system.

Supplementary Materials: The following supporting information can be downloaded at: https: / / www.mdpi.com/article/10.3390/en15031054/s1, Functions used to link HYSYS software, and MATLAB programming

Author Contributions: Conceptualization, A.K.J.; methodology, A.K.J.; software, A.K.J.; validation, A.K.J.; formal analysis, A.K.J.; writing-original draft preparation, A.K.J.; writing-review and editing, A.K.J., A.I. and B.G.; supervision, B.G. and A.I.; project administration, A.I. All authors have read and agreed to the published version of the manuscript.

Funding: This research received no external funding.

Informed Consent Statement: Not applicable.

Conflicts of Interest: The authors declare no conflict of interest. 


\begin{tabular}{|c|c|}
\hline \multicolumn{2}{|c|}{ Abbreviations } \\
\hline $\mathrm{CC}$ & Cold and hot composite curve \\
\hline GCC & Grand composite curve \\
\hline PSO & Particle Swarm Optimization \\
\hline $\mathrm{COP}$ & Coefficient of performance \\
\hline $\mathrm{LH}_{2}$ & Liquid hydrogen \\
\hline ACRC & Absorption-compression refrigeration cycle \\
\hline LNG & Liquid Natural Gas \\
\hline PCM & Phase Change Materials \\
\hline $\mathrm{CHP}$ & Combined heat and power \\
\hline BFD & Block flow diagram \\
\hline LNG & Liquefied natural gas \\
\hline PFD & Process flow diagram \\
\hline MRC & Multi-component refrigerant cycle \\
\hline ORC & Organic Rankine cycle \\
\hline SEC & Specific energy consumption $(\mathrm{kWh} / \mathrm{kg} \mathrm{LH} 2)$ \\
\hline \multicolumn{2}{|c|}{ Component name } \\
\hline Comp & Compressor \\
\hline MR & Methanol reactor \\
\hline SEP & Separator \\
\hline $\mathrm{HX}$ & Heat exchanger \\
\hline Turb & Turbine \\
\hline Pump & Pump \\
\hline $\mathrm{V}^{1}$ & Throttling valve \\
\hline $\mathrm{HE}$ & Heater \\
\hline $\mathrm{T}$ & Distillation tower \\
\hline MIX & Mixer \\
\hline \multicolumn{2}{|c|}{ Subscripts } \\
\hline Reb & Reboiler \\
\hline Con & Condenser \\
\hline $\mathrm{ph}$ & Physical \\
\hline ch & Chemical \\
\hline o (out) & Outlet \\
\hline i (in) & Inlet \\
\hline $\min$ & Minimum \\
\hline \multicolumn{2}{|c|}{ Greek letters } \\
\hline$\theta$ & Angle of incidence \\
\hline$\eta$ & Efficiency \\
\hline$\gamma$ & Activity coefficient \\
\hline$\Sigma$ & Sum \\
\hline$\Delta$ & Delta \\
\hline \multicolumn{2}{|c|}{ Nomenclature } \\
\hline $\mathrm{I}_{\mathrm{b}}$ & Direct of beam radiation $\left(\mathrm{kW} / \mathrm{m}^{2}\right)$ \\
\hline $\mathrm{I}_{\mathrm{d}}$ & Sky diffuse radiation $\left(\mathrm{kW} / \mathrm{m}^{2}\right)$ \\
\hline$\dot{\mathrm{m}}$ & Mass flow rate $\left(\mathrm{kg} \cdot \mathrm{s}^{-1}\right)$ \\
\hline $\mathrm{A}_{\mathrm{g}}$ & Glass coverage area $\left(\mathrm{m}^{2}\right)$ \\
\hline $\mathrm{A}_{\mathrm{a}}$ & Area of collector opening $\left(\mathrm{m}^{2}\right)$ \\
\hline $\mathrm{A}_{\mathrm{r}}$ & Area of receiver $\left(\mathrm{m}^{2}\right)$ \\
\hline $\mathrm{D}_{0}$ & Outer diameter of tubular receiver $(\mathrm{m})$ \\
\hline $\mathrm{D}_{\mathrm{g}}$ & Diameter of glass coverage $(\mathrm{m})$ \\
\hline$\overline{\mathrm{h}}_{0}^{\mathrm{b}}$ & Enthalpy in ambient condition $\left(\mathrm{kJ} \cdot \mathrm{kg}^{-1}\right)$ \\
\hline$\overline{\mathrm{s}}_{0}$ & Entropy in ambient condition $\left(\mathrm{kJ} \cdot \mathrm{kg}^{-1} \cdot \mathrm{K}^{-1}\right)$ \\
\hline$\dot{E x}_{\mathrm{ph}}$ & Physical exergy rate \\
\hline$\dot{E x} x_{c h}$ & Chemical exergy rate $(\mathrm{kW})$ \\
\hline
\end{tabular}




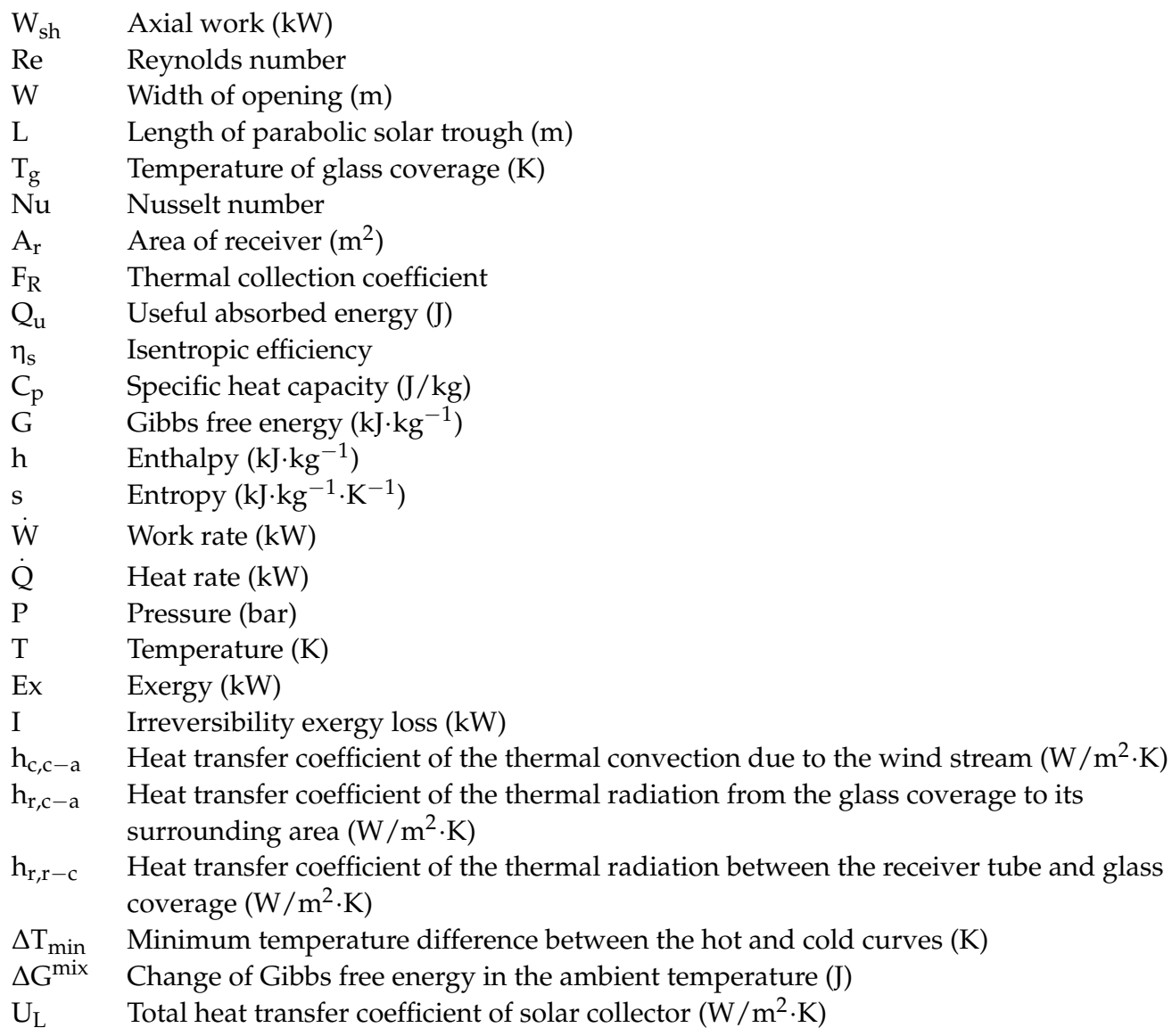

\section{Appendix A. Validation of the Developed Integrated Structure}

Partial validation was used to validate the integrated structure for power, heat, and liquid methanol cogeneration. The cryogenic hydrogen purification and the absorptioncompression refrigeration cycles of the integrated structure were compared with similar processes available in industries or resources in which related data are reported, and the accuracy of results is validated. In Table A1, the main parameters of the cryogenic hydrogen purification cycle are validated with the studies carried out by Asadnia et al. [7] and Mehrpooya et al. [6], including the required precooling and low-temperature cooling, the hydrogen content in the purified outlet stream, and exergy efficiency. Mehrpooya et al. [6] used the absorption-diffusion refrigeration cycle, Asadnia et al. [7] used the propane compression cycle, and the present paper used the absorption-compression refrigeration cycle to provide cooling.

Table A1. Validation of the main parameters of the cryogenic hydrogen purification cycle.

\begin{tabular}{|c|c|c|c|c|}
\hline Parameter & Present Study & Mehrpooya et al. [6] & Asadnia et al. [7] & Unit \\
\hline Type of refrigeration cycle & $\begin{array}{l}\text { Absorption- } \\
\text { compression }\end{array}$ & Diffusion-absorption & $\begin{array}{c}\text { Propane } \\
\text { compression }\end{array}$ & \\
\hline $\begin{array}{l}\text { Required refrigeration for } \\
\text { precooling }\end{array}$ & 0.0024 & 0.07125 & 0.00227 & $\mathrm{kWh} / \mathrm{kg}$ ISC * \\
\hline $\begin{array}{c}\text { Required } \mathrm{N}_{2} \text { for } \\
\text { low-temperature cooling }\end{array}$ & 0.001962 & 0.00196 & 0.001962 & $\mathrm{kWh} / \mathrm{kg}$ ISC \\
\hline Purity of the separated hydrogen & $88 \%$ molar & 88 & 88 & $\%$ molar \\
\hline Exergy efficiency & $92.83 \%$ & 93.825 & 91.73 & $\%$ \\
\hline
\end{tabular}

${ }^{*}$ ISC: Inlet unpurified stream.

Results showed that the data from the developed integrated structure in the present study had acceptable accordance with data from references depicted in Table A2. As the result of supplying cooling at a lower temperature $\left(-42.07^{\circ} \mathrm{C}\right)$, a COP improvement occurred in this paper compared to that in $[22,24,25]$. 
Table A2. Validation of the main parameters of the developed integrated structure.

\begin{tabular}{cccc}
\hline Item & Mixture & COP & $\begin{array}{c}\text { Refrigerant Temperature } \\
\text { (Evaporator), }{ }^{\circ} \mathbf{C}\end{array}$ \\
\hline This study & $\mathrm{H}_{2} \mathrm{O} / \mathrm{N}_{2} / \mathrm{CO}_{2}$ & 0.3031 & -42.07 \\
Chen et al. [25] & $\mathrm{H}_{2} \mathrm{O} / \mathrm{NH}_{3} / \mathrm{CO}_{2}$ & 0.277 & -55 \\
Mehrpooya et al. [22] & $\mathrm{H}_{2} \mathrm{O} / \mathrm{NH}_{3} / \mathrm{CO}_{2}$ & 0.2539 & -54.62 \\
Mousavi et al. [24] & $\mathrm{H}_{2} \mathrm{O} / \mathrm{NH}_{3} / \mathrm{CO}_{2}$ & 0.268 & -54.62 \\
\hline
\end{tabular}

The result of the comparison between the liquid methanol production cycle in the present study and the work carried out by Hosseini et al. [15] is available in Table A3, showing appropriate accordance between the present and reference paper. Parameters that are compared include wasted heat of the methanol reactor, required heat of the reboiler, wasted heat of the solar thermal collectors, and the purity of the produced liquid methanol.

Table A3. Validation of the main parameters of the liquid methanol production cycle.

\begin{tabular}{|c|c|c|c|c|}
\hline Parameters & Unit & This Study & $\begin{array}{l}\text { Hosseini } \\
\text { et al. [15] }\end{array}$ & $\begin{array}{l}\text { Relative } \\
\text { Error }\end{array}$ \\
\hline Pressure drop & $\mathrm{kPa}$ & 2000 & 2000 & 0 \\
\hline $\begin{array}{l}\text { Heat released from methanol } \\
\text { reactor to methanol production }\end{array}$ & $\mathrm{kWh} / \mathrm{kmol}$ & 16.83 & 17.1 & -1.604 \\
\hline $\begin{array}{l}\text { Required heat of reboiler to } \\
\text { methanol production }\end{array}$ & $\mathrm{kWh} / \mathrm{kmol}$ & 23.19 & 23.32 & -0.5605 \\
\hline $\begin{array}{l}\text { Wasted heat of the condenser to } \\
\text { methanol production }\end{array}$ & $\mathrm{kWh} / \mathrm{kmol}$ & 11.2 & 11.2 & 0 \\
\hline Condenser temperature & ${ }^{\circ} \mathrm{C}$ & 138.5 & 138.5 & 0 \\
\hline Reboiler temperature & ${ }^{\circ} \mathrm{C}$ & 180.3 & 180.3 & 0 \\
\hline Methanol purity & $\%$ & 99.8 & 99.8 & 0.0601 \\
\hline $\begin{array}{l}\text { Reactor's inlet mixture rate to the } \\
\text { methanol production }\end{array}$ & - & 4.424 & 4.423 & 15.81 \\
\hline External reflux ratio & & 1.3 & 1.3 & 0 \\
\hline
\end{tabular}

Thermodynamic characteristics of streams, including temperature, pressure, and flow rate, are provided in Table A4.

Table A4. The used streams thermodynamic characteristics.

\begin{tabular}{|c|c|c|c|c|c|c|c|}
\hline & Temp. & Press. & Flow & & Temp. & Press. & Flow \\
\hline & ${ }^{\circ} \mathrm{C}$ & $\mathrm{kPa}$ & $\mathrm{kmol} / \mathrm{h}$ & & ${ }^{\circ} \mathrm{C}$ & $\mathrm{kPa}$ & $\mathrm{kmol} / \mathrm{h}$ \\
\hline A1 & 138.06 & 1000 & 361.1 & D3 & -25 & 551.581 & 313.81 \\
\hline $\mathrm{A} 2$ & 35 & 100 & 9003.07 & D4 & -25 & 344.738 & 70.69 \\
\hline A3 & 139.96 & 2500 & 361.1 & D5 & -23.33 & 4481.59 & 1025.72 \\
\hline A4 & 192.5 & 2500 & 361.1 & D6 & -32 & 4481.59 & 1025.72 \\
\hline A5 & 153.95 & 1000 & 361.1 & D7 & -34.44 & 4481.59 & 1025.72 \\
\hline A6 & 153.95 & 1000 & 189.58 & D8 & -34.44 & 4481.59 & 1012.89 \\
\hline A9 & 28.42 & 1000 & 189.58 & D11 & -134.44 & 4481.59 & 1012.89 \\
\hline A10 & 153.95 & 1000 & 171.52 & D12 & -134.44 & 4481.59 & 699.08 \\
\hline B1 & 25 & 100 & $13,218.05$ & D13 & -134.44 & 4481.59 & 313.81 \\
\hline B2 & 30 & 100 & $13,218.05$ & D14 & -141.68 & 551.581 & 313.81 \\
\hline B3 & 165 & 100 & 1803.49 & D15 & -40 & 551.581 & 313.81 \\
\hline B6 & 199.01 & 100 & 461.93 & D18 & -148.89 & 4309.22 & 628.39 \\
\hline B7 & 200 & 100 & 461.93 & D19 & -140 & 4309.22 & 628.39 \\
\hline B8 & 143 & 100 & 461.93 & D20 & -46.9 & 4309.22 & 628.39 \\
\hline B9 & 25 & 100 & 1983.39 & D21 & -41.64 & 4309.22 & 628.39 \\
\hline
\end{tabular}


Table A4. Cont.

\begin{tabular}{|c|c|c|c|c|c|c|c|}
\hline & Temp. & Press. & Flow & & Temp. & Press. & Flow \\
\hline & ${ }^{\circ} \mathrm{C}$ & $\mathrm{kPa}$ & $\mathrm{kmol} / \mathrm{h}$ & & ${ }^{\circ} \mathrm{C}$ & $\mathbf{k P a}$ & $\mathrm{kmol} / \mathrm{h}$ \\
\hline B10 & 143 & 100 & 461.93 & D22 & -155 & 2294.85 & 25.82 \\
\hline B11 & 25 & 100 & 260.97 & D23 & -148.89 & 4309.22 & 70.69 \\
\hline B13 & 139.9 & 100 & 318.61 & D25 & -144 & 344.738 & 70.69 \\
\hline $\mathrm{C} 1$ & -41.61 & 4309.22 & 628.39 & E2 & -42.07 & 900 & 7.21 \\
\hline $\mathrm{C} 2$ & 25 & 4300 & 149.92 & E3 & 81.33 & 4000 & 7.21 \\
\hline $\mathrm{C} 3$ & -33.92 & 4300 & 778.32 & $\mathrm{E} 4$ & -15.41 & 4000 & 7.21 \\
\hline $\mathrm{C} 4$ & 180 & 4300 & 778.32 & E6 & 30 & 100 & 584.4 \\
\hline C6 & 200 & 5000 & 778.32 & E8 & 30 & 100 & 155.22 \\
\hline C10 & 43.37 & 2000 & 297.4 & F3 & -14 & 217 & 5.86 \\
\hline C11 & 95 & 2000 & 297.4 & $\mathrm{~F} 4$ & 14.2 & 217 & 5.86 \\
\hline C12 & 180.32 & 1000 & 149.34 & F5 & 61.08 & 217 & 31.78 \\
\hline C13 & 138.55 & 1000 & 148.06 & F6 & 35 & 217 & 31.78 \\
\hline C14 & 127.82 & 1000 & 148.06 & F7 & 35.24 & 1356 & 31.78 \\
\hline C15 & 127.82 & 1000 & 148.06 & F8 & 35.24 & 1356 & 19.09 \\
\hline C16 & 127.82 & 1000 & 0 & F9 & 35.24 & 1356 & 12.7 \\
\hline C17 & 50.11 & 1000 & 149.34 & F10 & 113.85 & 1356 & 12.7 \\
\hline D1 & -73.33 & 4481.59 & 1025.72 & F15 & 138.26 & 1356 & 25.92 \\
\hline D2 & -25 & 1723.69 & 12.82 & F16 & 66.1 & 1356 & 25.92 \\
\hline
\end{tabular}

\section{References}

1. Dehghani Madvar, M.; Alhuyi Nazari, M.; Tabe Arjmand, J.; Aslani, A.; Ghasempour, R.; Ahmadi, M.H. Analysis of stakeholder roles and the challenges of solar energy utilization in Iran. Int. J. Low-Carbon Technol. 2018, 13, 438-451. [CrossRef]

2. Abdin, Z.; Tang, C.; Liu, Y.; Catchpole, K. Large-scale stationary hydrogen storage via liquid organic hydrogen carriers. iScience 2021, 24, 102966. [CrossRef] [PubMed]

3. Rezaie Azizabadi, H.; Ziabasharhagh, M.; Mafi, M. Applicability of the common equations of state for modeling hydrogen liquefaction processes in Aspen HYSYS. Gas Process. J. 2021, 9, 11-28.

4. Sherif, S.; Zeytinoglu, N.; Veziroğlu, T. Liquid hydrogen: Potential, problems, and a proposed research program. Int. J. Hydrogen Energy 1997, 22, 683-688. [CrossRef]

5. Muin, N.A.A.; Isah, A.N.; Asli, U.A.; Sadikin, A.N.; Norazahar, N.; Kamaruddin, M.J.; Hassim, M.H.; Shin, H.W.; Azman, N.R. A Short Review on Various Purification Techniques Suitable for Biohydrogen-Mixed Gases. J. Energy Saf. Technol. (JEST) 2020, 3, 1-9.

6. Mehrpooya, M.; Mousavi, S.A.; Asadnia, M.; Zaitsev, A.; Sanavbarov, R. Conceptual design and evaluation of an innovative hydrogen purification process applying diffusion-absorption refrigeration cycle (Exergoeconomic and exergy analyses). J. Clean. Prod. 2021, 316, 128271. [CrossRef]

7. Aasadnia, M.; Mehrpooya, M.; Ghorbani, B. A novel integrated structure for hydrogen purification using the cryogenic method. J. Clean. Prod. 2021, 278, 123872. [CrossRef]

8. Hamedi, H.; Karimi, I.A.; Gundersen, T. Optimal cryogenic processes for nitrogen rejection from natural gas. Comput. Chem. Eng. 2018, 112, 101-111. [CrossRef]

9. $\mathrm{Xu}, \mathrm{J} . ; \mathrm{Lin}, \mathrm{W}$. Research on systems for producing liquid hydrogen and LNG from hydrogen-methane mixtures with hydrogen expansion refrigeration. Int. J. Hydrogen Energy 2021, 46, 29243-29260. [CrossRef]

10. $\mathrm{Xu}, \mathrm{J}$.; Lin, W. Integrated hydrogen liquefaction processes with LNG production by two-stage helium reverse Brayton cycles taking industrial by-products as feedstock gas. Energy 2021, 227, 120443. [CrossRef]

11. Xu, J.; Lin, W.; Xu, S. Hydrogen and LNG production from coke oven gas with multi-stage helium expansion refrigeration. Int. J. Hydrogen Energy 2018, 43, 12680-12687. [CrossRef]

12. Stiles, A.B. Methanol, past, present, and speculation on the future. AIChE J. 1977, 23, 362-375. [CrossRef]

13. Olah, G.A. Beyond oil and gas: The methanol economy. Angew. Chem. Int. Ed. 2005, 44, 2636-2639. [CrossRef] [PubMed]

14. Bertau, M.; Offermanns, H.; Plass, L.; Schmidt, F.; Wernicke, H.-J. Methanol: The Basic Chemical and Energy Feedstock of the Future; Springer: Berlin/Heidelberg, Germany, 2014; Volume 1.

15. Hosseini, S.S.; Mehrpooya, M.; Alsagri, A.S.; Alrobaian, A.A. Introducing, evaluation and exergetic performance assessment of a novel hybrid system composed of MCFC, methanol synthesis process, and a combined power cycle. Energy Convers. Manag. 2019, 197, 111878. [CrossRef]

16. Mosaffa, A.; Ghaffarpour, Z.; Farshi, L.G. Thermoeconomic assessment of a novel integrated CHP system incorporating solar energy based biogas-steam reformer with methanol and hydrogen production. Sol. Energy 2019, 178, 1-16. [CrossRef]

17. Ishaq, H.; Dincer, I. Evaluation of a wind energy based system for co-generation of hydrogen and methanol production. Int. J. Hydrogen Energy 2020, 45, 15869-15877. [CrossRef] 
18. Nami, H.; Ranjbar, F.; Yari, M. Thermodynamic assessment of zero-emission power, hydrogen and methanol production using captured CO2 from S-Graz oxyfuel cycle and renewable hydrogen. Energy Convers. Manag. 2018, 161, 53-65. [CrossRef]

19. Monnerie, N.; Gan, P.G.; Roeb, M.; Sattler, C. Methanol production using hydrogen from concentrated solar energy. Int. J. Hydrogen Energy 2020, 45, 26117-26125. [CrossRef]

20. Ghorbani, B.; Mehrpooya, M.; Bahnamiri, F.K. An integrated structure of bio-methane/bio-methanol cogeneration composed of biogas upgrading process and alkaline electrolysis unit coupled with parabolic trough solar collectors system. Sustain. Energy Technol. Assess. 2021, 46, 101304. [CrossRef]

21. Ghorbani, B.; Amidpour, M. Energy, exergy, and sensitivity analyses of a new integrated system for generation of liquid methanol, liquefied natural gas, and crude helium using organic Rankine cycle, and solar collectors. J. Therm. Anal. Calorim. 2021, 145, 1485-1508. [CrossRef]

22. Mehrpooya, M.; Ghorbani, B.; Mousavi, S.A.; Zaitsev, A. Proposal and assessment of a new integrated liquefied natural gas generation process with auto-Cascade refrigeration (exergy and economic analyses). Sustain. Energy Technol. Assess. 2020, 40, 100728. [CrossRef]

23. Chen, Y.; Han, W.; Jin, H. Analysis of an absorption/absorption-compression refrigeration system for heat sources with large temperature change. Energy Convers. Manag. 2016, 113, 153-164. [CrossRef]

24. Mousavi, S.A.; Mehrpooya, M. A comprehensive exergy-based evaluation on cascade absorption-compression refrigeration system for low temperature applications-exergy, exergoeconomic, and exergoenvironmental assessments. J. Clean. Prod. 2020, 246, 119005. [CrossRef]

25. Chen, Y.; Han, W.; Jin, H. Proposal and analysis of a novel heat-driven absorption-compression refrigeration system at low temperatures. Appl. Energy 2017, 185, 2106-2116. [CrossRef]

26. Chen, L.; Jiang, Q.; Song, Z.; Posarac, D. Optimization of methanol yield from a Lurgi reactor. Chem. Eng. Technol. 2011, 34, 817-822. [CrossRef]

27. Alfellag, M.A.A. Modeling and Experimental Investigation of Parabolic Trough Solar Collector. Master's Thesis, Embry-Riddle Aeronautical University, Daytona Beach, FL, USA, 2014.

28. Kalogirou, S.A. Solar Energy Engineering: Processes and Systems; Academic Press: Cambridge, MA, USA, 2013.

29. Noroozian, A.; Mohammadi, A.; Bidi, M.; Ahmadi, M.H. Energy, exergy and economic analyses of a novel system to recover waste heat and water in steam power plants. Energy Convers. Manag. 2017, 144, 351-360. [CrossRef]

30. Ebrahimi, A.; Ziabasharhagh, M. Optimal design and integration of a cryogenic Air Separation Unit (ASU) with Liquefied Natural Gas (LNG) as heat sink, thermodynamic and economic analyses. Energy 2017, 126, 868-885. [CrossRef]

31. Kotas, T.J. The Exergy Method of Thermal Plant Analysis; Elsevier: Amsterdam, The Netherlands, 2013.

32. Naeimi, A.; Bidi, M.; Ahmadi, M.H.; Kumar, R.; Sadeghzadeh, M.; Nazari, M.A. Design and exergy analysis of waste heat recovery system and gas engine for power generation in Tehran cement factory. Therm. Sci. Eng. Prog. 2019, 9, 299-307. [CrossRef] 